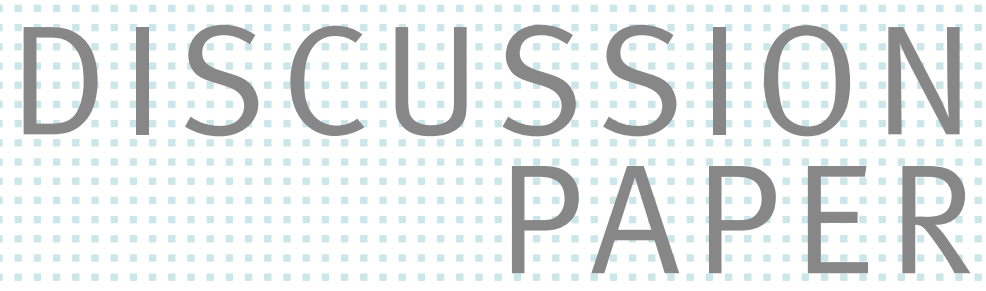

// DANIEL KLEIN, CHRISTOPHER LUDWIG, KATHARINA NICOLAY, AND CHRISTOPH SPENGEL

\title{
Quantifying the OECD BEPS Indicators - an Update to BEPS Action 11
}




\title{
Quantifying the OECD BEPS Indicators -
}

\section{An update to BEPS Action 11}

January 2021

\author{
Daniel Klein \\ University of Mannheim \\ d.klein@uni-mannheim.de
}

Katharina Nicolay
ZEW Mannheim \& University of Mannheim
katharina.nicolay@zew.de

\author{
Christopher A. Ludwig \\ ZEW Mannheim \& University of Mannheim \\ christopher.ludwig@zew.de \\ Christoph Spengel \\ University of Mannheim \& ZEW Mannheim \\ spengel@uni-mannheim.de
}

\begin{abstract}
:
In its 2015 Final Report on "Measuring and Monitoring BEPS, Action 11", the OECD introduced six indicators to quantify and evaluate base erosion and profit shifting (BEPS) activity over time. In this study, we revisit three selected indicators, provide a numerical update for recent periods using timely data and point out potential pitfalls when interpreting the indicator results. First, we transparently replicate Indicator 1, which intends to assess the disconnect between financial and real economic activities, and show a moderately decreasing trend of the indicator estimates. Second, replicating Indicator 4, which is based on a micro-data regression approach, we find that multinational firms have, on average, lower effective tax rates than domestic firms. We confirm this result using a state-of-the-art propensity score matching approach. Third, the replication of Indicator 5, which intends to capture profit shifting through intangibles, shows a stable trend of the annual indicator estimates that extends beyond the OECD's sample period. Yet, the simplistic design of all indicators comes at the price of making them vulnerable to a number of confounding factors and economic effects that go beyond profit shifting. Overall, we conclude that the proposed indicators in the Final Report on BEPS Action 11 provide only limited information on the extent of BEPS.
\end{abstract}

JEL: H20, H25, H26, L25

Keywords: Tax, Tax policy, International Taxation, BEPS, OECD, Base Erosion and Profit Shifting, Business Taxation, Corporate Tax Regulations

We thank Nadine Riedel, Johannes Voget, the participants of the joint Tax Foundation and European Tax Policy Forum (ETPF) 2020 conference and the participants of the Mannheim Taxation Campus Meeting 2020 for valuable comments. This paper was prepared for the joint Tax Foundation and ETPF conference on "The State of Uncertainty: Reflections on BEPS and the OECD's Two-Pillar Approach" in November 2020. We gratefully acknowledge financial support from the Graduate School of Economic and Social Sciences of the University of Mannheim and from the ETPF. 


\section{Introduction}

"The use of any indicators to identify the scale and economic impact of BEPS can only provide 'general indications' and the interpretation of any such indicators must be heavily qualified by numerous caveats.”

(OECD, 2015, p. 41)

Profit shifting of multinational corporations is a pressing topic in the public debate, academic research and on the political agenda. The debate on legal tax avoidance is fueled by anecdotal evidence on extremely low effective tax rates (ETRs) by multinational enterprises (MNEs). Especially, US companies with valuable intellectual property (IP), such as Google, Apple, and Amazon, are in the public focus for being tax 'aggressive'.

The issue of 'aggressive' tax planning and cross-border income relocation is, of course, not new to policymakers. The release of the well-known Action Plan on Base Erosion and Profit Shifting (BEPS) by the Organization for Economic Cooperation and Development (OECD) in 2013 has lifted the issue to one of the top priorities in international politics. Since then, many nations have implemented far-reaching reforms to prevent 'aggressive' income shifting, to strengthen anti-tax avoidance legislation and to conserve corporate tax revenues. While some reforms are part of coordinated supranational actions, e.g., the EU Anti-Tax Avoidance Directive, others are purely unilateral legislations to protect national tax revenues, e.g., the

\footnotetext{
${ }^{1}$ The effective tax rate of big tech companies is regularly discussed in the public media and Margarethe Vestager, European Commissioner for Competition, has become publicly known for her focus on illegal state aid cases and tax affair investigations. See, for example, https://www.ft.com/content/79b56392-dde5-11e8-8f50cbae5495d92b; https://www.theguardian.com/technology/2018/oct/08/facebook-uk-tax-bill-sales-margarethodge and https://www.bloomberg.com/news/articles/2019-09-16/apple-takes-on-eu-s-vestager-in-record-14billion-tax-battle.
} 
French Digital Services Tax. Prominently, the OECD has recently proposed a far-reaching twopillar reform to adjust the worldwide corporate tax system. ${ }^{2}$

Despite the proposed actions to prevent BEPS and the heightened public awareness against 'aggressive' tax planning, it is still a major challenge to credibly measure the extent of profit shifting and to assess its economic relevance (Blouin and Robinson, 2019; Bradbury et al., 2018; Tørsløv et al., 2018). In the 2015 published Final Report on "Measuring and Monitoring BEPS, Action 11", the OECD introduced six indicators to measure and evaluate BEPS activity over time and on different levels of aggregation (OECD, 2015). The six OECD BEPS indicators intend to identify the scale and economic impact of BEPS, track changes in BEPS over time and monitor the effectiveness of measures implemented to reduce BEPS (OECD, 2015). In conjunction with the introduction, the OECD provides numbers for each indicator for the period from 2005 to 2012. These values are interpreted to provide strong signals on the existence and exacerbation of BEPS (Bradbury and O'Reilly, 2018). However, ever since these indicators have not been revised or quantitatively updated by the OECD.

In this paper, we transparently replicate a selection of the six OECD indicators to measure and monitor BEPS. We provide an update to the numbers underlying the ongoing political debate to reform the global corporate income tax system. Our work builds on the theoretical evaluation of the indicators by Heckemeyer et al. (2021). The authors argue that the main objective of the OECD BEPS indicators, to provide understandable and easy to replicate measures of BEPS, comes at the price of too simplistic measures that prevent a reliable tracing of profit shifting. It is beyond the scope of this paper to conceptually re-assess whether the indicators are well suited to capture profit shifting. Our aim is to provide a numerical update and to point out potential pitfalls when interpreting the indicator values; because we agree that

\footnotetext{
2 Pillar One proposes a "Unified Approach" that is designed to allocate taxing rights to market jurisdictions (Beer et al., 2020; OECD, 2020a). Pillar Two, the "Global Anti-Base Erosion" (GloBE) proposal, intends to counteract all remaining profit shifting risks by introducing a coordinated global minimum tax and a deduction disallowance that should, in general, apply to all transactions (Devereux et al., 2020; OECD, 2020b).
} 
a broad range of estimates on the existence and extent of profit shifting is necessary to provide policymakers with a solid foundation for any decision making and evaluation of policy actions.

We categorize the six OECD BEPS indicators in three different groups based on their underlying data and measurement rationale. The first indicator group uses macro data to highlight a potential disconnect between financial and real economic activities. This category comprises Indicator 1: Concentration of foreign direct investment relative to the Gross Domestic Product (GDP). The second group uses micro data to identify surprisingly low profit or tax measures. This category comprises Indicator 2: Differential profit rates compared to effective tax rates; Indicator 3: Differential profit rates between low-tax locations and worldwide MNE operations; and Indicator 4: Effective tax rates of large MNE affiliates relative to non-MNE entities with similar characteristics. The third indicator group uses micro and macro data to measure the use of potential profit shifting channels. This category comprises Indicator 5: Concentration of high levels of royalty receipts relative to R\&D spending; and Indicator 6: Interest expense to income ratios of MNE affiliates in high-tax locations. We revive one indicator from each category to shed light on its development over time. Our choice relies on the assessment in Heckemeyer et al. (2021) and we are confident to focus on the most convincing indicator in each category, namely Indicator 1, Indicator 4 and Indicator 5.

Indicator 1 relies on macro-level data and intends to indirectly measure BEPS that takes place through the use of offshore tax havens. By replicating this indicator, we transparently show that countries that are often expected to serve as conduits or final destinations for BEPS have a disproportionately high amount of gross or net FDI in relation to economic activity measured by GDP. Extrapolating the indicator values to recent years reveals a downward (stable) trend for the relation of average net (gross) FDI to GDP ratios between countries with very high and lower concentrations of FDI relative to their economic activity. However, since the indicator is unable to distinguish between real economic activity and BEPS, the estimates 
and their variation over time may be driven by factors unrelated to BEPS, such as trade openness or business cycles.

Indicator 4 employs firm-level micro data to evaluate cross-border profit shifting of multinational corporations and addresses the well-known drawbacks of highly aggregated macro data. Due to the usage of advanced statistical methods and counterfactuals, Indicator 4 has been identified in previous work to represent the most promising approach (Heckemeyer et al., 2021). Replicating the OECD's regression, we show that the ETR differential between MNE and non-MNE affiliates is negative and statistically significant for almost all years in our sample. Yet, the difference diminishes over time. In line with Bilicka (2019), we extend the OECD's fourth indicator by applying a propensity score matching approach. The qualitative insight holds. MNEs tend to have lower effective tax rates than comparable domestic firms. Despite the promising approach to compare MNEs with similar domestic firms, the ETR is by construction not suitable to capture profit shifting. If at all, the recommended measure indicates certain forms of special tax incentives, loss-offsets, hybrid mismatch arrangements, tax negotiations or other non-profit shifting related methods to reduce a firm's tax burden.

Indicator 5 relies again on macro-data rather than firm-level data and is concerned with profit shifting through intangibles. We show that countries with high ratios of royalty receipts to research and development spending, which builds the rationale of Indicator 5, are countries with low corporate income tax rates or IP box regimes, e.g., Ireland, the Netherlands and Luxembourg. Moreover, the indicator remains constant over time and does not seem to react to recent policy actions to curb BEPS. However, the simplistic design of Indicator 5, which lacks any link to countries' tax rates, is to some extent arbitrary and completely neglects potential real economic activities of MNEs.

Our analysis shows that despite the OECD's intention to provide a dashboard of indicators to evaluate the existence and scale of BEPS and to measure and monitor how BEPS evolves over time, the indicators presented in the Final Report on BEPS Action 11 are unlikely 
to achieve this goal convincingly. Their simplistic design comes at the price of making them vulnerable to a number of confounding factors and economic effects that go beyond profit shifting. The OECD (2015) acknowledges several shortcomings of their indicators itself and our selected replication of three indicators confirms these issues. Overall, the indicators provide only limited information on the extent of profit shifting and lack the ability to precisely identify any changes to BEPS that result from recent tax reforms and enactments of BEPS countermeasures.

With this transparent replication and update of simple indicator values that are taken as a rationale for global tax reforms, we contribute to the public and political debate on profit shifting of MNEs. However, we recommend to base policy decision on the numerous empirical studies that in general exploit well-specified identification strategies and granular data to show the existence of BEPS and to develop convincing estimates of the level of income shifting and the effects of BEPS countermeasures (Hanlon and Heitzman, 2010; Heckemeyer and Overesch, 2017; Riedel, 2018; Wilde and Wilson, 2018). The academic debate on the extent of BEPS and its fiscal effects has recently gained momentum (Blouin and Robinson, 2019; Bradbury et al., 2018; Tørsløv et al., 2018). Blouin and Robinson (2019) critically discuss the broad range of profit shifting estimates and assess different data sources. Especially, the careful evaluation of new data such as public country by country reporting can shed light on the extent of profit shifting (Clausing, 2020; Dutt et al., 2019). Moreover, analyzing different profit shifting channels separately allows to apply targeted measures and data sources and provides a promising approach to evaluate the effectiveness of specific BEPS countermeasures (Beer and Loeprick, 2015; Clausing, 2003; Dischinger and Riedel, 2011; Lohse and Riedel, 2013; Overesch, 2016; Saunders-Scott, 2015).

This paper is organized as follows. Section 2 covers the replication of Indicator 1, the concentration of foreign direct investment relative to GDP. The subsequent section covers the replication of Indicator 4, the comparison of effective tax rates of large MNE affiliates with 
non-MNE entities. Section 4 covers the replication of Indicator 5, profit shifting through intangibles. Each section has three major subsections. First, we describe the methodology and data necessary to estimate each indicator. Second, we show the results and third, we critically assess the rationale and shortcomings of the indicators. Finally, section 5 concludes.

\section{Concentration of foreign direct investment relative to GDP}

"This macro-economic indicator is the ratio of the stock of FDI to a country's GDP, measure of real economic activity. The indicator compares the FDI ratio in countries with relatively high values of FDI to GDP ratios to the same ratio in the rest of the included countries."

(OECD, 2015, p. 49)

\subsection{Methodology and data}

OECD Indicator 1 relies on macro-level data and intends to indirectly measure BEPS that takes place through the use of offshore tax havens, which is the strategy of MNEs to channel funds to affiliates in low-tax countries for tax purposes. In order to measure the movement of funds, the OECD focuses on foreign direct investments (FDI). FDI measures the amount of crossborder investments of related affiliates and includes not only investments related to BEPS but also to real economic activity. As FDI patterns can generally be expected to be proportional to the economic size of the involved countries (Head and Ries, 2008), significantly high concentrations of FDI to GDP may signal BEPS. Following these considerations, Indicator 1 is based on the ratio of FDI stock in a country owned by foreign investors to the GDP of that country in a given year. Based on the magnitude of this ratio in a pre-determined base year, countries are assigned to two different groups - high-ratio countries and low-ratio countries and remain in this group in all years. For each group, the average of the ratio of FDI stock to GDP is determined and the indicator expands as follows: 


$$
\text { Indicator } 1_{t}=\frac{\frac{\sum_{i=1}^{I} F D I_{i, t}}{\sum_{i=1}^{I} G D P_{i, t}}}{\frac{\sum_{j=1}^{J} F D I_{j, t}}{\sum_{j=1}^{J} G D P_{j, t}}}
$$

where subscript $i$ refers to countries in the high-ratio group and subscript $j$ to countries in the low-ratio group.

The OECD distinguishes between two different measures of FDI. The net FDI of a country is calculated as the inward FDI stock in that country owned by foreign investors from OECD countries less the outward FDI stock from domestic investors that is held in OECD countries. Hence, this measure is supposed to identify those countries that are the ultimate destination of foreign direct investments for the purpose of BEPS. The OECD determines a threshold of 50 percent of the net FDI to GDP ratio for assigning countries into the two groups.

The second measure of FDI relies on the gross inward FDI stock in a country owned by foreign investors from OECD countries. In addition to countries that are the ultimate destinations for FDI, this measure is intended to also capture conduit countries with a high proportion of FDI stock relative to GDP. The OECD defines a threshold of 200 percent of gross FDI to GDP for assigning countries into the two groups.

We replicate both measures using 2012 and 2018 as the base years for group allocation. We also conduct the analyses by recalculating the two groups continuously on a yearly basis. For our calculations, we employ two different sets of data from the OECD Foreign Direct Investment Statistics. We firstly use FDI position data of the $3^{\text {rd }}$ edition of the Benchmark Definition of FDI (BMD3). The data includes inward and outward FDI positions from and to OECD countries for the time period from 2005 to 2013. Secondly, we use FDI position data of the $4^{\text {th }}$ edition of the Benchmark Definition of FDI (BMD4) for the time periods from 2014 to 
2018. ${ }^{3}$ Additionally, we obtain GDP data in current US dollar for the years 2005 until 2018 from the World Bank. ${ }^{4}$ The dispersion of countries with available data is shown in Table 1.

Moreover, the BMD4 data allow us to observe FDI inflows and outflows of special purpose entities (SPEs). As defined by the OECD, SPEs are established in economies other than those in which the parent firm is resident and engage primarily in international transactions but in few or no local operations. Therefore, FDI in SPEs might be considered especially BEPSmotivated.

\subsection{Results}

First, we replicate the OECD's estimation of Indicator 1, taking net FDI to GDP as the measure and 2012 as the base year. For 2012, we have data on 202 countries, of which 14 are assigned to the high-ratio group. Unsurprisingly, members of the high-ratio group are countries with low or no CIT rate or preferential tax systems, e.g., the Bahamas, Cayman Islands or Ireland. The structure of the high-ratio group is depicted in Table 2 Panel A. Using the BMD3 data from 2005 to 2012, we can closely replicate the results of the OECD, which are shown in Table 3 Panel A and graphically plotted in Figure 1. In 2011, the indicator shows that the average ratio of net FDI to GDP of the high-ratio countries was about 43 times higher than the average ratio of low-ratio countries. The indicator values are depicted in Figure 2. However, we do not find the OECD's sharp increase in the indicator value in the year 2012, in which our estimate increases to 54.8 in contrast to 99.2 estimated by the OECD. Employing the BMD4 data from 2013 onwards, we see a drop in the indicator value to 23.9 , which then steadily decreases to 11.7 in 2018.

When taking 2018 as the base year for group allocation, we identify 13 countries in the high-ratio group, which is depicted in the right column of Table 2 Panel A. In 2005 and 2006,

\footnotetext{
${ }^{3}$ Since September 2014, the OECD has been collecting FDI statistics from member countries according to the updated benchmark definition BMD4. The methodology of the FDI statistics published between 1990 and end2013 relates to the 3rd edition of the benchmark definition.

${ }^{4}$ World Bank indicator code: NY.GDP.MKTP.CD
} 
the average ratio of net FDI to GDP of the high-ratio group was only marginally higher. After this time, we find a steady increase to an indicator value of around 14 , which remains stable until 2018.

Second, we replicate the OECD's indicator using the gross FDI to GDP ratio. The OECD claims that by using gross FDI values, the indicator also captures those countries that function as conduits for BEPS. When using 2012 as the base year, ten out of 202 countries are assigned to the high-ratio group and, indeed, countries such as Ireland, the Netherlands and Luxembourg are part of the high-ratio group which are considered as members of the top ten conduit countries (van 't Riet and Lejour, 2018). Table 2 Panel B displays the list of all countries in the high-ratio group. From 2005 to 2012, we are able to closely replicate the OECD's estimates. Table 3 Panel B depicts the indicator values. In 2005, the gross FDI to GDP ratio of the highratio countries is about 12 times higher than the ratio of the low-ratio countries and doubles to 24 until 2012. In the following years, the indicator value remains at a level of about 23. Figure 3 shows that in 2018, the amount of gross FDI per euro of GDP in the high-ratio group of countries was, on average, 19 times higher than the average ratio for the remaining countries. When taking 2018 as the base year, eleven countries belong to the high-ratio group and Figure 4 shows that the indicator trend over time is steadily increasing and doubles between 2005 and 2018.

In addition, we repeat both analyses allocating countries to into high and low-ratio groups on a continuous basis every year. For the net FDI analysis, the indicator value follows closely that of taking 2012 as base year, as depicted in Figure 5. The gross FDI indicator, which is shown in Figure 6 ranges between 60 and 100 for the years 2005 to 2010. This is about five times the value of that when taking 2012 as base year. In year 2011, the indicator value drops to 24 and remains in this magnitude for the rest of the sample period.

As robustness test, we replicate our analysis keeping only those countries for which we have data available over the whole period from 2005 to 2018 and find very similar results. 
Furthermore, we exploit FDI positions of SPEs in the time period from 2013 to 2018. Due to the variation in data availability, we do not find consistent results. Nevertheless, the prior identified countries in the high-ratio groups are again those countries with the highest ratios.

\subsection{Rationale and shortcomings}

Indicator 1 relies on the assumption that a country's magnitude of (inward) FDI stock to GDP provides an indication of BEPS. Specifically, MNEs are supposed to channel funds to low-tax countries for tax reasons and not for reasons of real economic activity. Indeed, prior literature provides evidence on the adverse relationship of taxes and FDI (Buettner et al., 2018; Desai et al., 2004; Janeba, 1995). BEPS related FDI is expected to create a disproportion between the FDI in a country and the economic activity of this country, measured by GDP. The indicator intends to capture this disproportion. However, the definition of the indicator has many drawbacks. First, FDI includes both investments related to BEPS and investments related to real economic activity. Since the indicator is unable to distinguish between these types of investment, the estimates and their variation over time may be driven by factors unrelated to BEPS, such as trade openness or business cycles. Second, the indicator does not provide any direct linkage to countries' tax rates which is the key driver for BEPS related FDI. Third, the indicator values highly depend on the specific threshold and base year to assign countries to the two different groups. This is highlighted by the high indicator value dispersion when using continuous base years. Overall, we explicitly point out that the results have to be treated with caution and conclude that Indicator 1 does not provide convincing (indirect) evidence of BEPS.

\section{Effective tax rates of large MNE affiliates compared to non-MNE entities}

"Indicator 4 compares the ETRs of large MNE affiliates with non-MNE entities with similar characteristics in the same country. The indicator measures the extent to which large MNE affiliates have lower ETRs than comparable non-MNE entities."

(OECD, 2015, p. 58). 


\subsection{Methodology and data}

This OECD indicator relies on firm-level micro data to evaluate cross-border profit shifting of MNEs and addresses the well-known drawbacks of highly aggregated macro data that is used to estimate the first OECD Indicator. In contrast to purely domestic firms, which operate only in one country, MNEs have incentives to relocate income to affiliates located in countries with lower corporate tax rates. The fourth OECD indicator exploits this difference between domestic and multinational corporations. Domestic firms serve as a counterfactual benchmark group to assess the extent of income shifting by comparable multinationals. The indicator uses financial data of multinational and domestic firms and compares the average effective tax rate (ETR) of both groups. The OECD expects that the ETR of MNEs is, on average, lower than that of comparable domestic firms (OECD, 2015).

The presumption of lower ETRs for MNEs is tested using the following regression framework: ${ }^{5}$

$$
\operatorname{ETR}_{f, c, i, t}=\beta_{1} \operatorname{large}_{f, c, i, t} x \text { year }_{t}+\beta_{2} \operatorname{large}_{f, c, i, t} x M N E_{f, c, i} x \operatorname{year}_{t}+\beta_{3} X_{f, c, i, t}+\delta_{i}+\delta_{c, t}
$$

where $E T R_{f, c, i, t}$ is the effective tax rate for firm $f$ in country $c$, industry $i$ and year $t$. The ETR is the ratio of tax payments to earnings before income and taxes (EBIT) in percent. Large $_{f, c, i, t}$ is a dummy variable that takes the value of 1 for firms with more than 250 employees and 0 otherwise. Multinational firms are identified using the dummy variable $M N E_{f, c, i}$. The group structure is based on the ORBIS ownership information at the end of year 2016 and we restrict the sample to majority owned firms and headquarters. The group structure is assumed to be constant in our panel. ${ }^{6}$ We require a multinational group to have at least one cross-border relationship. $\beta_{2}$, the estimated coefficient of the interaction between large and multinational

\footnotetext{
${ }^{5}$ Note that the regression framework deviates slightly from the regression stated in Annex 3. A1 in OECD (2015). We only exclude the dummy variable small, which is the exact counterpart to the variable large. We further directly interact the coefficient of interest (and its baseline effect) with a year dummy to obtain yearly estimates, as presented in Table 2.3. Indicator 4 in OECD (2015).

${ }^{6}$ This assumption is commonly used in the literature on profit shifting. Many changes in the ownership structure result from data improvements by the data provider.
} 
firms, is the coefficient of interest and the estimated value of Indicator 4. We exclude the baseline effect of multinationals on the ETR to obtain a direct estimate of the OECD's verbally expressed difference between the ETR of large multinational and large domestic corporations. Year $_{t}$ is a dummy variable that is interacted with the coefficient of interest to provide yearly estimates. $X_{f, c, i, t}$ is a vector of firm-specific control variables. It includes the size of a firm, measured as the logarithm of total assets, the profitability ratio of a firm and an estimate for the degree of firms' innovation activities. We use the ratio of intangible to total assets as a proxy for firms' innovativeness in contrast to the number of patents that is used by the OECD. Furthermore, a dummy variable that indicates if a firm is the global ultimate owner controls for a firm's position in the group. $\delta_{i}$ are industry fixed effects at the two-digit NACE classification and $\delta_{c, t}$ are country-year fixed effects.

In line with the OECD, we use unconsolidated financial data from the well-known Bureau van Dijk ORBIS database to replicate the estimates of Indicator 4. Our panel starts in 2000 and has data up to 2016. Similar to other studies on profit shifting, we exclude observations with implausible financial data such as total assets below 0 and exclude all observations that have a negative effective tax rate or one above 100 percent (Beer and Loeprick, 2015; Dischinger and Riedel, 2011; Huizinga and Laeven, 2008). Furthermore, we restrict the sample to firms with a profitability ratio, which is determined as EBIT to total assets, between 0 and 100 percent, i.e., we exclude loss-making firms and overly profitable corporations. Finally, we exclude all firms with less than three years of basic accounting data available in our panel (Beer and Loeprick, 2015).

\subsection{Results}

Our panel from 2000 to 2016 consists of more than 800,000 firms, thereof about 18 percent are multinational firms. Descriptive statistics are depicted in Table 4. In our baseline regression, depicted in Table 5, we estimate large MNEs to have a 0.96 percentage points lower 
ETR than comparable large domestic firms, which is significant at the one percent level. This estimate decreases to about -1.5 if we only consider the period from 2000 until 2010 that corresponds to the OECD sample period. Yet, the OECD estimates that the ETR of large MNEs is, on average, three percentage points below the ETR of comparable large domestic corporations (OECD, 2015). We replicate the yearly estimates of the ETR differential in Table 6. The interaction coefficient of large and multinational corporations is directly comparable to the estimates of Indicator 4 in the final report on BEPS Action 11. Our estimates on the differential between large MNE affiliates and non-MNE entities are considerably below the annual estimates of the OECD. We plot the yearly coefficients and the confidence interval in Figure 7. Yet, we also see a negative and statistically significant ETR differential for almost all years. The ETR differential follows for the second half of our sample period - that extends beyond the OECD's period - an upward trend and converges towards zero.

We conduct several robustness tests. First, we restrict the sample to specific regions. In column 3 of Table 6, we only consider firms located in an OECD country, and in column 4, we only consider firms located in EU countries. The results do not change materially. Second, we change the outcome variable to tax payments over total assets to account for the critique on the chosen outcome variable in the OECD regression approach (Heckemeyer et al., 2021). The regression is depicted in Table 7. The relative tax payments to total assets are, on average, only significantly lower for large MNEs than for large domestic firms in the early sample period.

\subsection{Additional analysis - Propensity score matching}

The OECD's regression approach to compare domestic and multinational corporations is an intuitive empirical methodology and the differences to alternative, more sophisticated, matching estimates are presumably of minor empirical importance (Angrist and Pischke, 2008). Yet, the quality of the comparison between multinational and domestic firms crucially hinges on the matching quality, i.e., the similarity and comparability of the two groups is essential for any inferences. A well-established method of creating a control group that is as similar as 
possible to the treaded group in a non-experimental setting is the so-called propensity score matching (Abadie and Imbens, 2006, 2016; Rosenbaum and Rubin, 1983; Rubin, 1974). Bilicka (2019) applies propensity score matching for a sample of UK MNEs and domestic firms to evaluate BEPS. The matching process follows a two-step procedure. First, the likelihood of firms being domestic or multinational is estimated based on observable characteristics. Second, domestic and multinational firms are matched based on the estimated propensity scores. The method excludes firms that are very unlikely to serve as a comparable benchmark group. The benefits of the propensity score matching approach go beyond the OECD's regression framework. First, a key advantage is the possibility to assess the similarity of the two groups of MNE affiliates and non-MNE entities at a glance after the first matching step. Second, the propensity score matching allows to fine tune the proximity of the two groups along the observable matching dimensions. Third, a successful matching allows to directly compare the variable of interest, here the average ETR, between the two groups.

Hence, we extend the OECD's fourth indicator by applying a propensity score matching approach to estimate the average treatment effect (ATE), i.e. the differential between the average ETR of MNE affiliates and non-MNE entities or the effect of being a multinational firm, on the effective tax rates. We borrow from Bilicka (2019) and match MNEs to domestic firms. We match firms based on the logarithm of total assets, the logarithm of firm's productivity, the debt to equity ratio and the ratio of intangible to total assets within year, industry and country. All observable characteristics, which we use in the matching process, should be similar in the matched sample. Table 8 shows how the similarity of the two groups improves in the matched sample. A solid sign of matching quality is a standardized difference between the samples of close to zero and a variance ratio of about one. On average, our matched sample approaches this standard for all observable matching characteristics within each country industry and year matching cluster. We then estimate the average treatment effect for each year in our sample. Table 9 depicts the yearly estimated treatment effect of being a multinational 
firm on the ETR. We have plotted the estimated average treatment effects in Figure 8. The estimated ETR differences range between -0.13 and -1.02 percentage points and do not follow a specific trend in our sample period. In comparison to the regression estimates, the differentials are slightly smaller in the first half of our sample period. Moreover, in several years the estimates are statistically indistinguishable from zero. The estimated effective tax rate differentials depend - as the choice of control variables in the OECD regression approach - on the specific observable characteristics used for the propensity score matching. Hence, alternative controls or matching characteristics could lead to differences in the magnitude of the estimated ETR differentials.

\subsection{Rationale and shortcomings}

Indicator 4 is the only indicator that includes the usage of counterfactuals as control group. This is the key advantage of Indicator 4 in contrast to all other suggested indicators to measure and monitor BEPS. However, the specifications of this indicator as defined by the OECD include other shortcomings that go beyond the matching quality that we have addressed in the preceding subsection.

It is highly questionable if the dependent variable ETR is a suitable measure to capture profit shifting. The ETR, which relates to tax expenditures over reported pre-tax profits, does not capture any of the known profit shifting channels such as transfer pricing, debt shifting nor royalty allocation (Heckemeyer et al., 2021). Specifically, the ETR's denominator is affected by profit shifting. By construction it can - if at all - indicate certain forms of special tax incentives, loss-offsets, hybrid mismatch arrangements, tax negotiations or other non-profit shifting related methods to reduce a firm's tax burden. Moreover, the unconsolidated ETR is rarely a key performance indicator of multinational corporations. Managers, and stakeholders rather focus on a group's overall tax burden, i.e. the consolidated ETR. In its current design, the indicator also neglects any differences within the group of multinational firms. While groups with affiliates in tax haven locations can be presumed to engage more actively in profit 
shifting, groups without links to low-tax jurisdictions might not have a strong incentive to relocate income.

\section{Profit shifting through intangibles}

"The indicator compares the average ratio of royalties received to $R \& D$ expenditures for a group of high-ratio countries to the average ratio for the other countries in the sample."

(OECD, 2015, p. 60)

\subsection{Methodology and Data}

OECD Indicator 5 relies on macro-data rather than firm-level data and is concerned with profit shifting through intangibles. Profit shifting through intangibles is commonly defined as the strategy of transferring IP from high-tax to low-tax countries for tax purposes after it has been developed in high-tax countries. Using this structure, affiliates in high-tax countries pay (potentially high amounts of) royalties for the use of the IP to affiliates in a low-tax country. The indicator shall indirectly capture the extent of BEPS through IP transfer. Following the logic of transferring IP to low-tax countries for tax purposes, IP receiving countries should have a higher ratio of royalty receipts to research and development (R\&D) spending compared to those countries where the IP was developed. For this reason, in a first step, the ratio of royalty receipts relative to $R \& D$ spending is measured for each country. Next, countries are assigned into two groups based on their concentration in a given year. Countries with a ratio above 50 percent are assigned to the group of high-ratio countries while the other countries form the group of low-ratio countries. By dividing the average ratio of the high-ratio group with the average ratio of the low-ratio group, Indicator 5 is formed for year $\mathrm{t}$ :

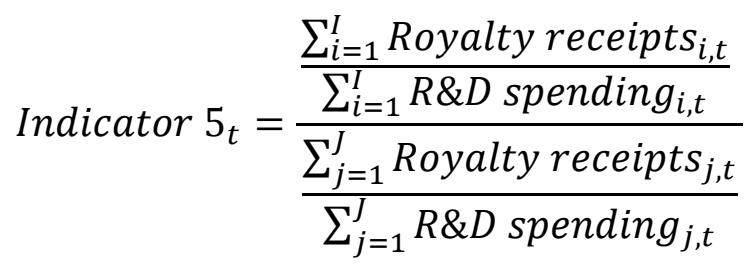


where the subscript $i$ refers to members of the high-ratio group and subscript $j$ to members of the low-ratio group in year $t$.

In its 2015 report, the OECD uses the year 2011 as the base year to identify the composition of the high-ratio and low-ratio group, which is held constant in the other years. We replicate the indicator using 2011 and 2017 as the base year. ${ }^{7}$ We also replicate the indicator by recalculating the two groups continuously on a yearly basis. Furthermore, we check the robustness of our results through different tests.

We obtain country-level data on receipts for the use of IP as balance of payments in current US dollar for the years 2005 to 2018 from the World Bank. ${ }^{8}$ Moreover, we use data on the gross domestic expenditure on R\&D from the UNESCO Institute for Statistics (UIS.Stat). ${ }^{9}$ The data availability is depicted in Table 10.

\subsection{Results}

First, we replicate the OECD's estimation of royalty receipts to R\&D spending and take 2011 as the base year for allocating countries into high-ratio and low-ratio groups. In 2011, data is available for 69 countries, of which eight countries are assigned to the high-ratio group. The structure of the high-ratio group is shown in Table 11. In fact, members of the high-ratio group are European countries with low corporate income tax rates or preferential tax systems. For example, Ireland, the Netherlands and Luxembourg are part of this group.

In the year 2011, the high-ratio countries received EUR 1.53 of royalty for every EUR 1 invested in R\&D while the low-ratio countries received only EUR 0.18. Thus, the ratio for the high-ratio countries is almost nine times larger than that of the low-ratio countries, which leads to an indicator value of 8.7. Table 12 provides annual estimates of Indicator 5. Over the years,

\footnotetext{
${ }^{7}$ We take 2017 instead of 2018 as the base year for data availability reasons.

${ }^{8}$ World Bank indicator code: BX.GSR.ROYL.CD

${ }^{9}$ The OECD names the World Development Indicators as its data source on R\&D expenditures. However, we could only find data on R\&D expenditures as a percentage of GDP. Using this data would have added even larger measurement error to our calculations. We verify our results using R\&D spending data from the OECD, where we obtain similar results.
} 
the indicator does not vary significantly. In 2005, the indicator takes a value of 7.7 , which increases until 2010 to 9.1 . After being stable for about three years, the indicator increases to 11.9 in 2015 but decreases again to 9.8 in the year 2017. Figure 9 plots the development of Indicator 5 graphically. In contrast to the estimates of the OECD, our estimated Indicator 5 value is higher but we do not observe a strong increase over time. Our estimates confirm that some countries receive comparably very high shares of royalties to R\&D spending. In 2011, the eight countries in the high-ratio group received about 13.4 percent of the overall royalties of the 69 countries examined.

Second, we take the year 2017 as a base year for group allocation to replicate the OECD's results. The group of high-ratio countries consists of nine countries, which are named in Table 11. Table 12 and Figure 10 depict the estimates. From 2005 to 2018, the indicator ranges between 3.5 and 5.7, taking its peak in 2017. Again, the indicator values seem to be stable over time and have about the same size as the OECD's estimates. The high-ratio countries received EUR 0.98 of royalties for every EUR 1 invested in R\&D in 2017, while the low-ratio countries received only EUR 0.17.

Third, we refrain from pre-determined group allocation but re-estimate the allocation of the high-ratio and low-ratio group every year. As shown in Figure 9, the indicator values range between 5.7 and 10.7 without a clear pattern over the years. The greater dispersion can be explained by the annual re-calculation of the sample for the indicator estimation. Nevertheless, the values do not exceed or fall below those of the samples with base years.

Finally, we test the robustness of our analysis using OECD data on R\&D spending. The results are depicted in Table 13 . Even though the R\&D data are only available for, on average, 37 countries, the results verify our previous findings. Furthermore, we replicate our analysis using only countries for which we have at least 10 years or 14 years of data available. Again, the values of the indicator do not change significantly. Lastly, we also obtain similar indicator results if we take the lag values of $R \& D$ spending for estimation. We do this to adjust for the 
possibility that between the time of receipts from royalty and the time of $R \& D$ spending a time gap exists.

\subsection{Rationale and shortcomings}

Previous research has shown that MNEs transfer intellectual property to affiliates located in countries with relatively lower corporate tax rates for BEPS reasons (Amberger and Osswald, 2020; Dischinger and Riedel, 2011; Karkinsky and Riedel, 2012). Indicator 5 is based on this rationale and aims to measure BEPS as the income stream generated by IP relative to the R\&D expenditures in a country. Specifically, this assumes that MNEs use the resources of industrial countries, which often levy higher corporate tax rates, for complex R\&D tasks and, subsequently, transfer the developed IP to countries with lower tax rates, causing a deviation between royalty payments and $R \& D$ expenditures.

However, the simplicity of the indicator leads to various shortcomings that need to be considered when interpreting the results. First, Indicator 5 is an indirect measure of BEPS and no assertion can be made about the scale of BEPS. Second, royalty payments may not only be linked to $R \& D$ spending but also to the use of trademarks, copyrights or franchises (Heckemeyer et al., 2021). Third, it is assumed that MNEs shift IP for tax reasons. However, the definition of the indicator neither provides a direct link to taxes nor does it capture the movement of IP. Thus, this indicator could, for example, also proxy R\&D productivity by capturing the difference between countries with highly valuable $R \& D$ and less valuable $R \& D$. Fourth, the proposed tax planning strategy of transferring IP from R\&D countries to low-tax countries may be limited and undesirable since exit-taxation could eliminate potential tax benefits (Ernst and Spengel, 2011). Fifth, even though we try to account for time lags between R\&D and IP output in robustness tests, the true time period is unobservable and potentially very diverse. Hence, the indicator variation over time might be misleading. Fifth, this indicator is on the aggregated country level and does not account for country size. Thus, small countries might 
be overrepresented. Lastly, the group assignment of the indicator depends on an arbitrarily chosen threshold without taking other factors into account.

\section{Conclusion}

Profit shifting of multinational firms is a pressing topic in the public debate, academic research and on the political agenda. Yet, measuring the extent of profit shifting and assessing the economic relevance of it is a major challenge. In its 2015 published Final Report on "Measuring and Monitoring BEPS, Action 11", the OECD has introduced six indicators to measure and evaluate BEPS activity over time and on different levels of aggregation. We replicate one indicator from each of the three subordinate categories and update the numbers underlying the ongoing political debate to reform the global corporate tax system. We build on the conceptual evaluation of the indicators by Heckemeyer et al. (2021) and focus our analysis on the most convincing indicators: Indicator 1 (Disconnect between financial and real economic activities), Indicator 4 (MNE vs. "comparable" non-MNE effective tax rate differentials) and Indicator 5 (Profit shifting through intangibles).

Following the OECD's specification, we closely replicate the estimates of Indicator 1, which intends to indirectly measure BEPS through the use of offshore tax havens. We transparently show that countries with low or no corporate income tax (CIT) rates or preferential tax systems, e.g., the Bahamas, Cayman Islands or Ireland, have very high concentrations of FDI relative to their GDP. Extrapolating the indicator to recent years, the net FDI to GDP ratio shows a moderately decreasing trend and the gross FDI to GDP ratio remains at a stable level. The replicated regression estimates of Indicator 4 show that multinational firms have lower effective tax rates than domestic firms. This difference diminishes over time. Our annual estimated ETR differential is lower even in the years that overlap with the OECD sample period. We repeat the analysis using a propensity score matching approach, finding similar results. The replication of Indicator 5, which is concerned with profit shifting through 
intangibles, shows a stable trend of the annual indicator estimates that extends beyond the OECD's sample period. Similar to the first indicator, we transparently show that countries with high ratios of royalty receipts to research and development (R\&D) spending are countries with low corporate income tax rates or IP box regimes, e.g., Ireland, the Netherlands and Luxembourg.

Overall, the OECD's intend to provide a convincing and simple dashboard of indicators that allows to evaluate the existence and scale of BEPS and to measure and monitor how BEPS evolves over time comes with a number of shortcomings. The indicators highly dependent on the underlying assumptions, the availability of data and may be influenced by various confounding factors beyond BEPS. Hence, the informative value of the indicators for policymakers is limited. Yet, transparent updates on the existence and extent of BEPS are important for the ongoing public and academic debate on the necessity to reform the corporate income tax system. We endorse the ongoing empirical research that exploits well-specified identification strategies and granular data to measure the existence and extent of BEPS and propose to tackle the issue from different angles. Only multidimensional approaches allow to develop a holistic view of BEPS and to evaluate ongoing proposals to reform the global corporate income tax system. 


\section{BIBLIOGRAPHY}

Abadie, A., and Imbens, G. W. (2006). Large sample properties of matching estimators for average treatment effects. Econometrica, 74(1), 235-267.

Abadie, A., and Imbens, G. W. (2016). Matching on the estimated propensity score. Econometrica, 84(2), 781-807.

Amberger, H., and Osswald, B. (2020). Patent Concentration, Asymmetric Information, and Tax-Motivated Income Shifting. SSRN Scholarly Paper. Retrieved from https://papers.ssrn.com/abstract=3600839.

Angrist, J. D., and Pischke, J.-S. (2008). Mostly harmless econometrics: An empiricist's companion. Princeton: Princeton university press.

Beer, S., and Loeprick, J. (2015). Profit shifting: Drivers of transfer (mis) pricing and the potential of countermeasures. International Tax and Public Finance, 22(3), 426-451.

Beer, S., Mooij, R. A., Hebous, S., Keen, M., and Liu, L. (2020). Exploring Residual Profit $\begin{array}{lllll}\text { Allocation. } & \text { SSRN } & \text { Scholarly } & \text { Paper. } & \text { Retrieved }\end{array}$ https://papers.ssrn.com/abstract=3583408.

Bilicka, K. A. (2019). Comparing UK Tax Returns of Foreign Multinationals to Matched Domestic Firms. American Economic Review, 109(8), 2921-2953.

Blouin, J., and Robinson, L. A. (2019). Double counting accounting: How much profit of multinational enterprises is really in tax havens? SSRN Scholarly Paper. Retrieved from https://papers.ssrn.com/abstract=3491451.

Bradbury, D., Hanappi, T., and Moore, A. (2018). Estimating the fiscal effects of base erosion and profit shifting: Data availability and analytical issues. Transnational Corporations, 25(2), 91-106. 
Bradbury, D., and O'Reilly, P. (2018). Inclusive fiscal reform: Ensuring fairness and transparency in the international tax system. International Tax and Public Finance, 25(6), 1434-1448.

Buettner, T., Overesch, M., and Wamser, G. (2018). Anti profit-shifting rules and foreign direct investment. International Tax and Public Finance, 25(3), 553-580.

Clausing, K. A. (2003). Tax-motivated transfer pricing and US intrafirm trade prices. Journal of Public Economics, 87(9), 2207-2223.

Clausing, K. A. (2020). Profit Shifting Before and After the Tax Cuts and Jobs Act. SSRN Scholarly Paper. Retrieved from https://papers.ssrn.com/abstract=3274827.

Desai, M. A., Foley, C. F., and Hines, J. R. (2004). Foreign direct investment in a world of multiple taxes. Journal of Public Economics, 88(12), 2727-2744.

Devereux, M. P., McCarthy, M., Simmler, M., Vella, J., Bares, F., Freedman, J., and Irem, G. (2020). The OECD Global Anti-Base Erosion Proposal. Retrieved from https://www.sbs.ox.ac.uk/sites/default/files/2020-

02/OECD_GloBE_proposal_report_2020.pdf.

Dischinger, M., and Riedel, N. (2011). Corporate taxes and the location of intangible assets within multinational firms. Journal of Public Economics, 95(7), 691-707.

Dutt, V. K., Nicolay, K., Vay, H., and Voget, J. (2019). Can European Banks’ Country-byCountry Reports Reveal Profit Shifting? An Analysis of the Information Content of EU Banks' Disclosures. ZEW-Discussion Paper. Retrieved from https://papers.ssrn.com/abstract=3472876.

Ernst, C., and Spengel, C. (2011). Taxation, R\&D tax incentives and patent application in Europe. ZEW-Discussion Paper. Retrieved from http://ftp.zew.de/pub/zewdocs/dp/dp11024.pdf.

Hanlon, M., and Heitzman, S. (2010). A review of tax research. Journal of Accounting and Economics, 50(2), 127-178. 
Head, K., and Ries, J. (2008). FDI as an outcome of the market for corporate control: Theory and evidence. Journal of International Economics, 74(1), 2-20.

Heckemeyer, J. H., Nicolay, K., and Spengel, C. (2021). What Will the OECD BEPS Indicators Indicate? ZEW-Discussion Paper.

Heckemeyer, J. H., and Overesch, M. (2017). Multinationals' profit response to tax differentials: Effect size and shifting channels. Canadian Journal of Economics/Revue Canadienne d'économique, 50(4), 965-994.

Huizinga, H., and Laeven, L. (2008). International profit shifting within multinationals: A multi-country perspective. Journal of Public Economics, 92(5), 1164-1182.

Janeba, E. (1995). Corporate income tax competition, double taxation treaties, and foreign direct investment. Journal of Public Economics, 56(2), 311-325.

Karkinsky, T., and Riedel, N. (2012). Corporate taxation and the choice of patent location within multinational firms. Journal of International Economics, 88(1), 176-185.

Lohse, T., and Riedel, N. (2013). Do transfer pricing laws limit international income shifting? Evidence from European multinationals. CESIfo Working Paper. Retrieved from https://ssrn.com/abstract=2334651.

OECD. (2015). Measuring and Monitoring BEPS, Action 11-2015 Final Report. Retrieved from https://www.oecd-ilibrary.org/taxation/measuring-and-monitoring-beps-action11-2015-final-report_9789264241343-en.

OECD. (2020a). Tax Challenges Arising from Digitalisation - Report on Pillar One Blueprint: Inclusive Framework on BEPS. Retrieved from https://www.oecdilibrary.org/taxation/tax-challenges-arising-from-digitalisation-report-on-pillar-oneblueprint_beba0634-en.

OECD. (2020b). Tax Challenges Arising from Digitalisation - Report on Pillar Two Blueprint: Inclusive Framework on BEPS. Retrieved from https://www.oecd- 
ilibrary.org/taxation/tax-challenges-arising-from-digitalisation-report-on-pillar-twoblueprint_abb4c3d1-en.

Overesch, M. (2016). Steuervermeidung multinationaler Unternehmen. Perspektiven Der Wirtschaftspolitik, 17(2), 129-143.

Riedel, N. (2018). Quantifying International Tax Avoidance: A Review of the Academic Literature. Review of Economics, 69(2), 169-181.

Rosenbaum, P. R., and Rubin, D. B. (1983). The central role of the propensity score in observational studies for causal effects. Biometrika, 70(1), 41-55.

Rubin, D. B. (1974). Estimating causal effects of treatments in randomized and nonrandomized studies. Journal of Educational Psychology, 66(5), 688.

Saunders-Scott, M. J. (2015). Substitution across methods of profit shifting. National Tax Journal, 68(4), 1099.

Tørsløv, T. R., Wier, L. S., and Zucman, G. (2018). The missing profits of nations. National Bureau of Economic Research Working Paper. Retrieved from http://www.nber.org/papers/w24701.

van 't Riet, M., and Lejour, A. (2018). Optimal tax routing: Network analysis of FDI diversion. International Tax and Public Finance, 25(5), 1321-1371.

Wilde, J. H., and Wilson, R. J. (2018). Perspectives on corporate tax planning: Observations from the past decade. The Journal of the American Taxation Association, 40(2), 63-81. 


\section{FIGURES}

\section{Figure 1: Indicator 1 - Net FDI to GDP by groups}

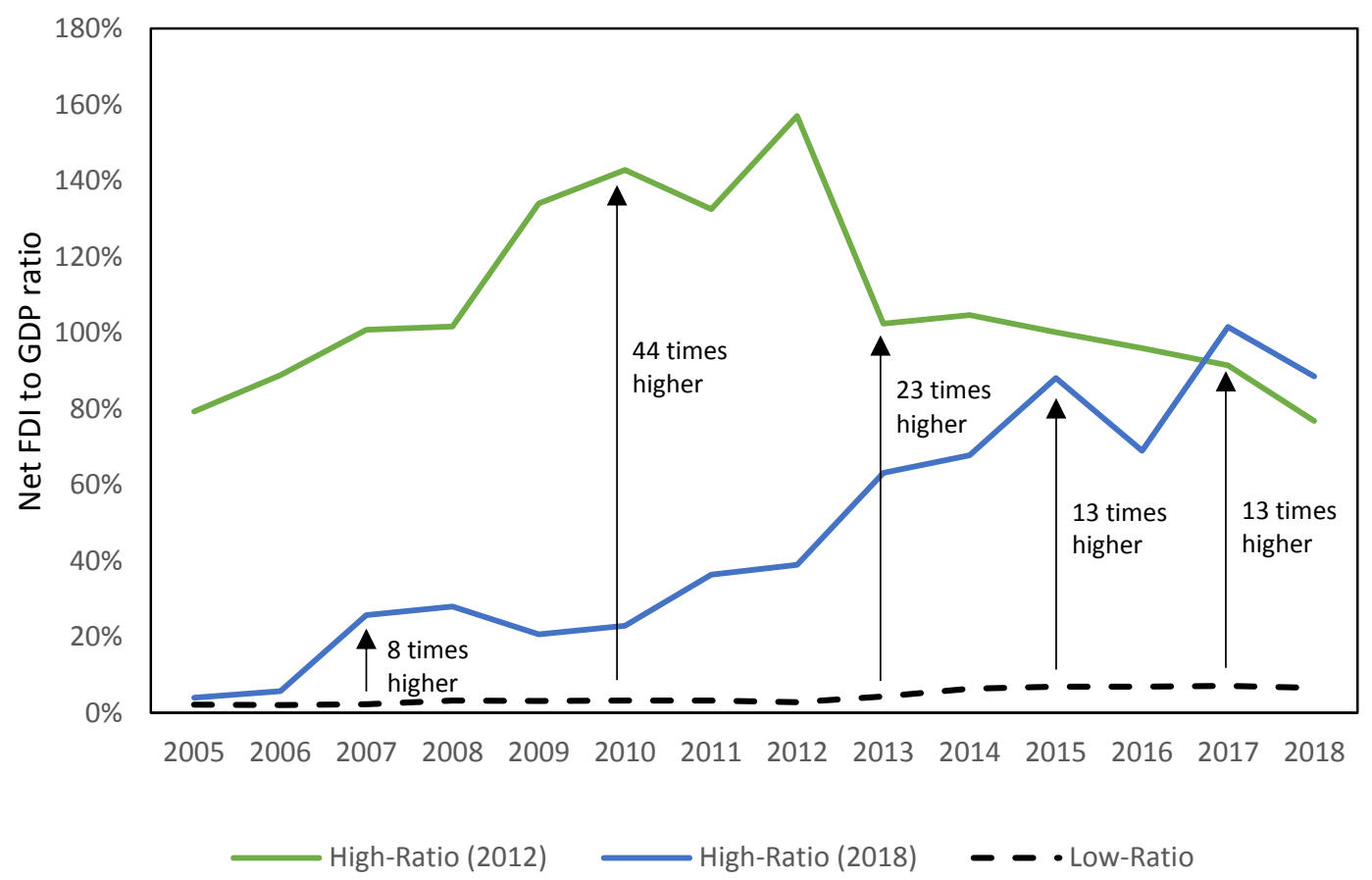

Notes: The green line depicts the trend of the average net FDI to GDP ratio for the group of countries that have a ratio above 0.5 in 2012. The blue line depicts the trend of the average net FDI to GDP ratio for the group of countries that have a ratio above 0.5 in 2018. The black dotted line displays the average ratio of the remaining (low-ratio) countries.

\section{Figure 2: Indicator 1 - Net FDI Indicator trend}

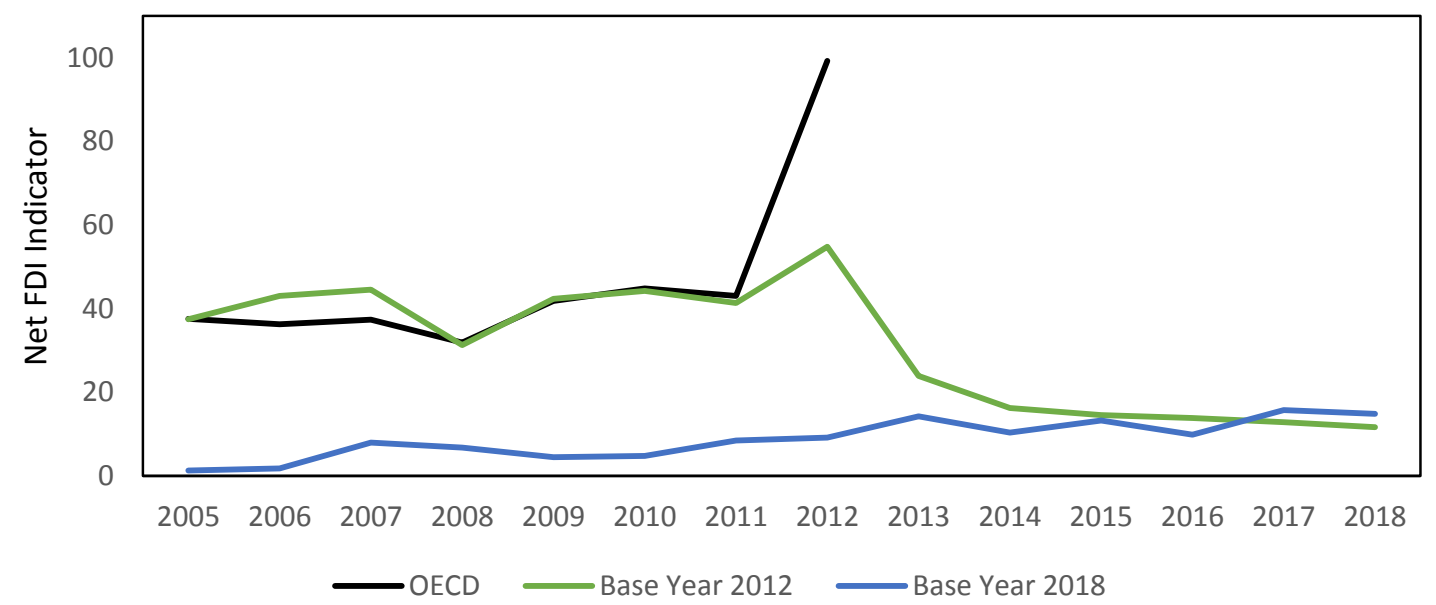

Notes: The green line shows the trend of Indicator 1 using net FDI to GDP as measure and 2012 as base year. The blue line uses 2018 as base year for group allocation. The black line shows the indicator's trend estimated by the OECD in 2015. 


\section{Figure 3: Indicator 1 - Gross FDI to GDP by groups}

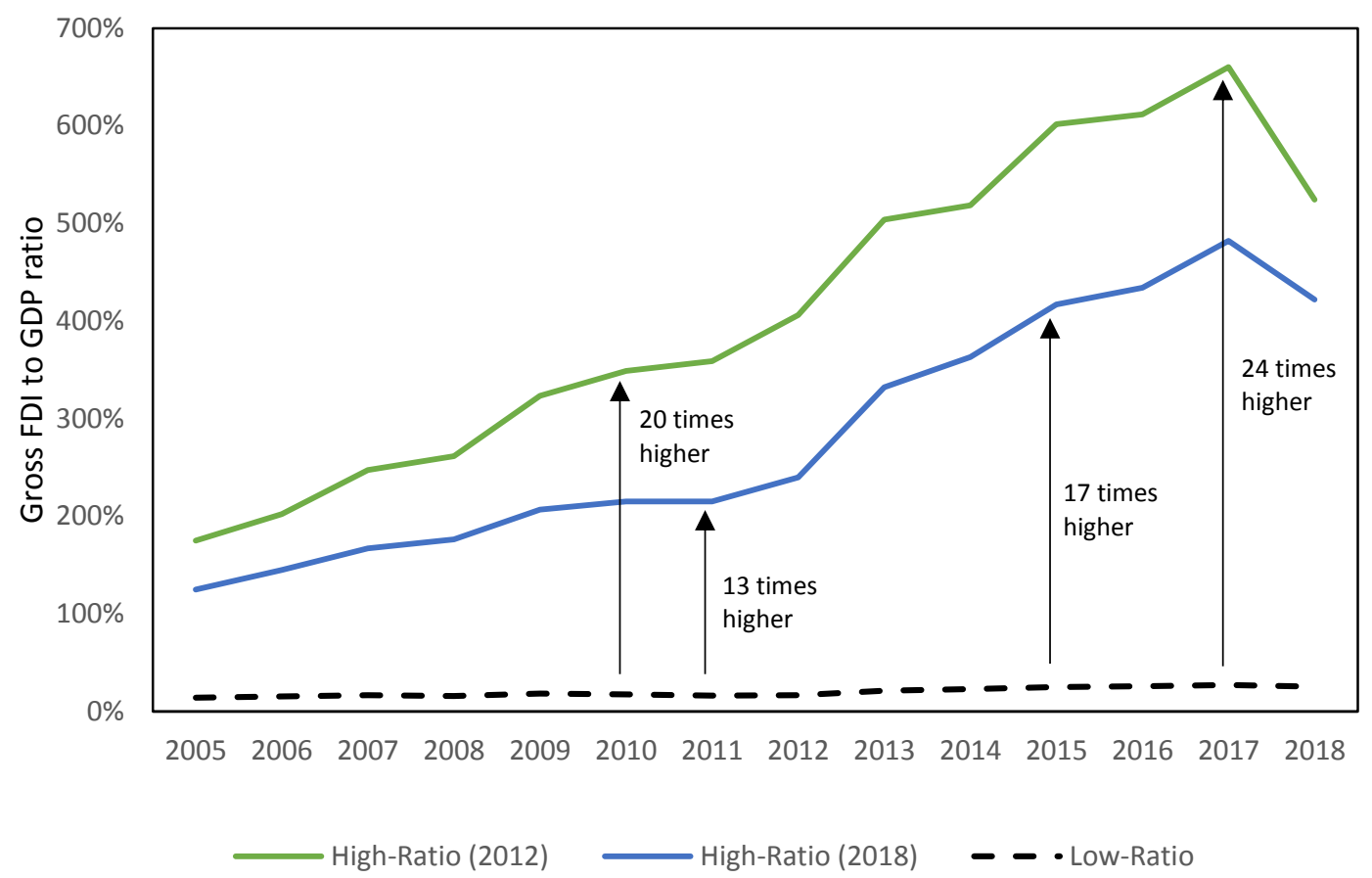

Notes: The green line depicts the trend of the average gross FDI to GDP ratio for the group of countries that have a ratio above 2.0 in 2012. The blue line depicts the trend of the average gross FDI to GDP ratio for the group of countries that have a ratio above 2.0 in 2018. The black dotted line displays the average ratio of the remaining (low-ratio) countries.

\section{Figure 4: Indicator 1 - Gross FDI Indicator trend}

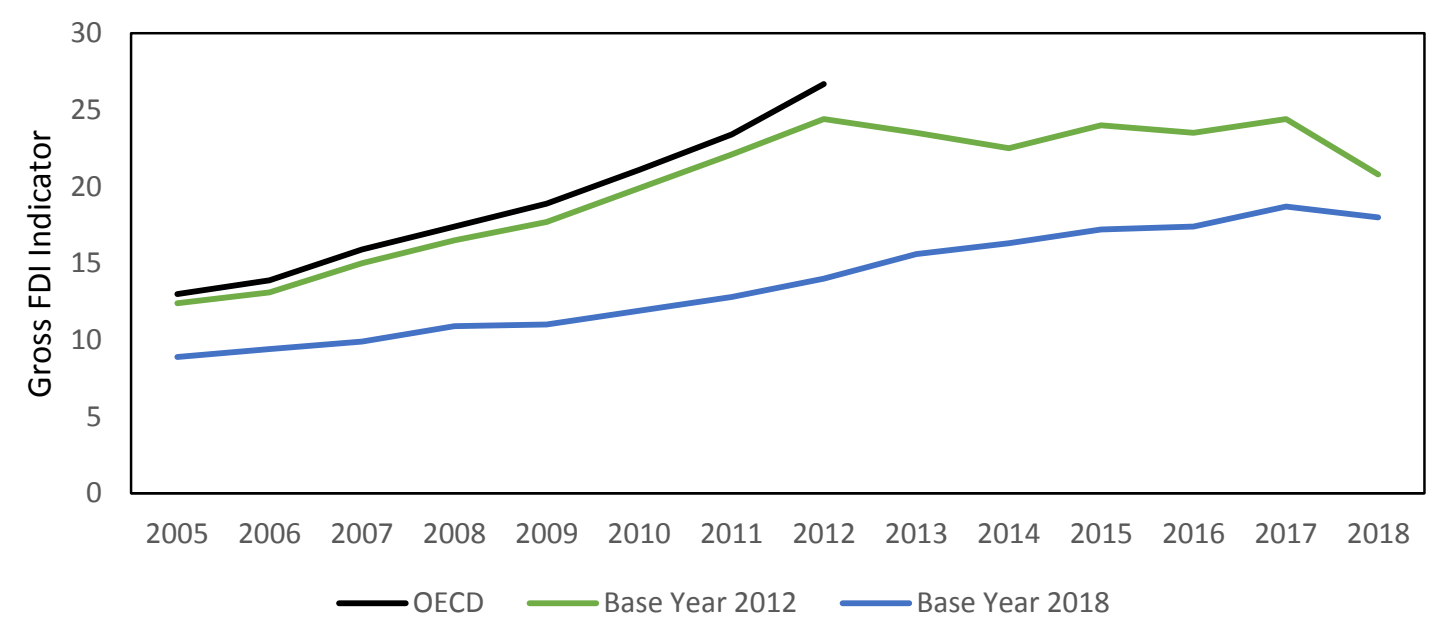

Notes: The green line shows the trend of Indicator 1 using net FDI to GDP as measure and 2012 as base year. The blue line uses 2018 as base year for group allocation. The black line shows the indicator's trend estimated by the OECD in 2015. 
Figure 5: Indicator 1 - Net FDI Indicator with continuous base year

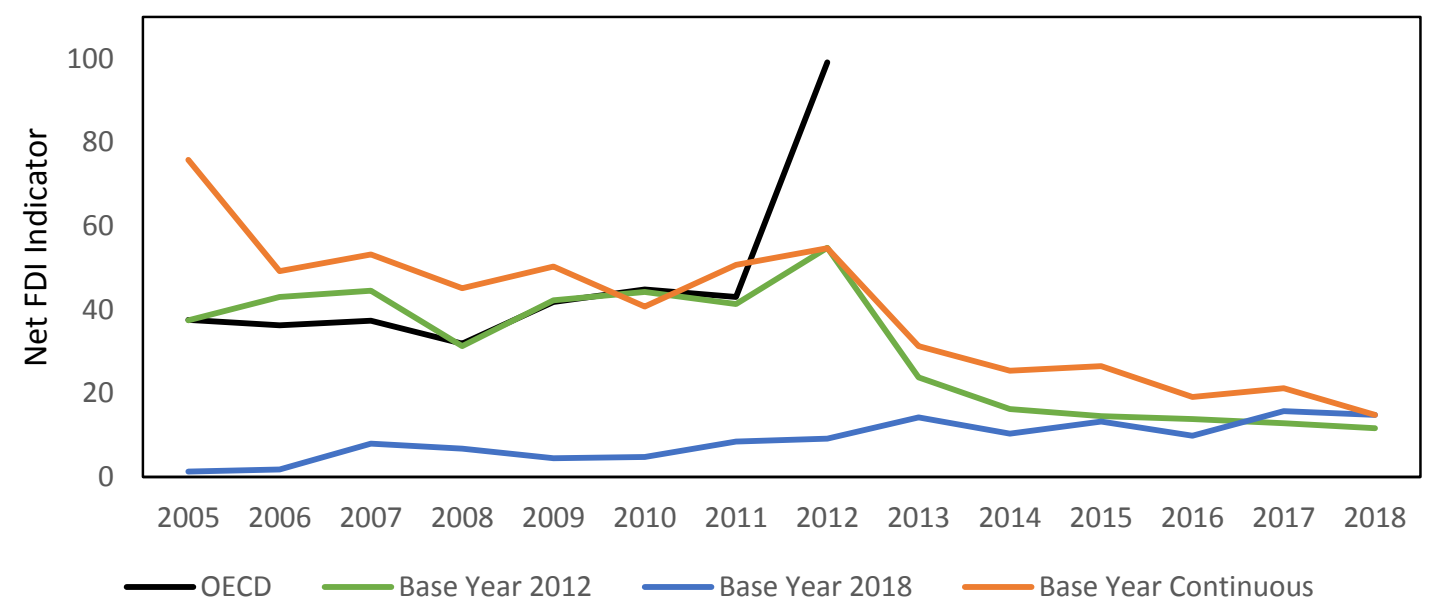

Notes: The green line shows the trend of Indicator 1 using net FDI to GDP as measure and 2012 as base year. The blue line uses 2018 as base year for group allocation. The orange line recalculates the group composition every year. The black line shows the indicator's trend estimated by the OECD in 2015.

\section{Figure 6: Indicator 1 - Gross FDI Indicator with continuous base year}

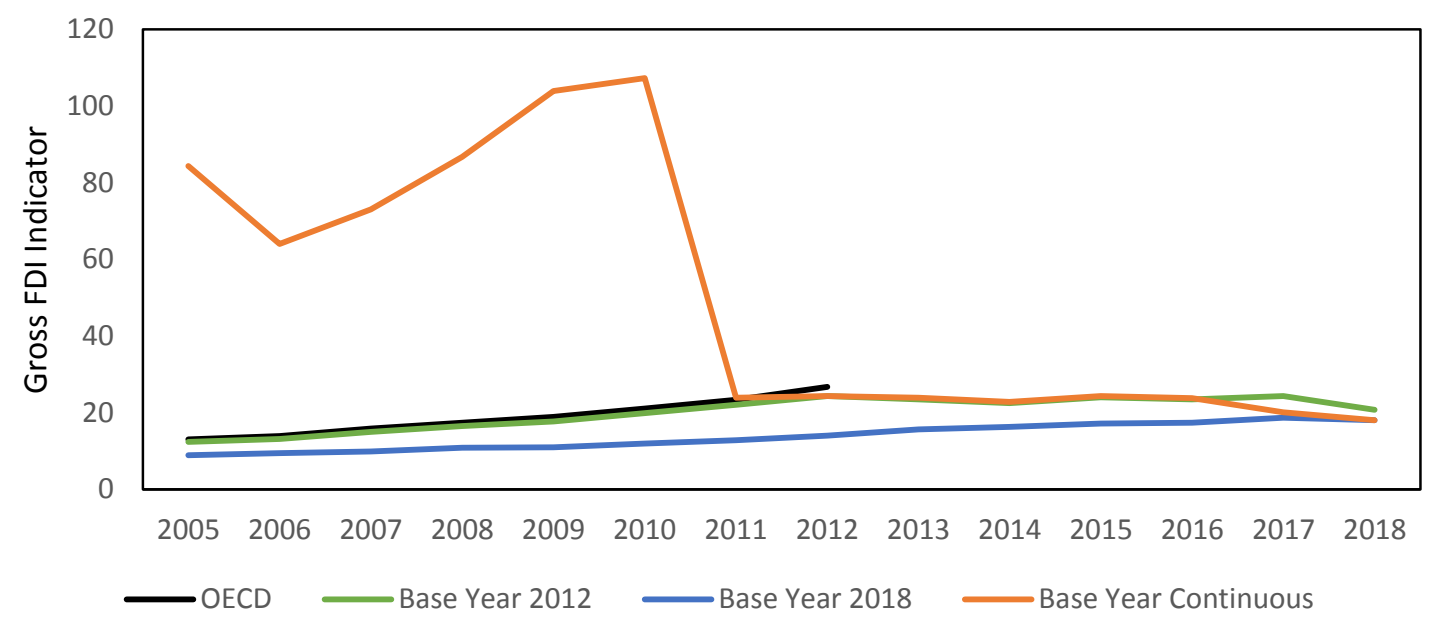

Notes: The green line shows the trend of Indicator 1 using gross FDI to GDP as measure and 2012 as base year. The blue line uses 2018 as base year for group allocation. The orange line recalculates the group composition every year. The black line shows the indicator's trend estimated by the OECD in 2015. 


\section{Figure 7: Indicator 4 - Trends in international tax planning, 2000-2016}

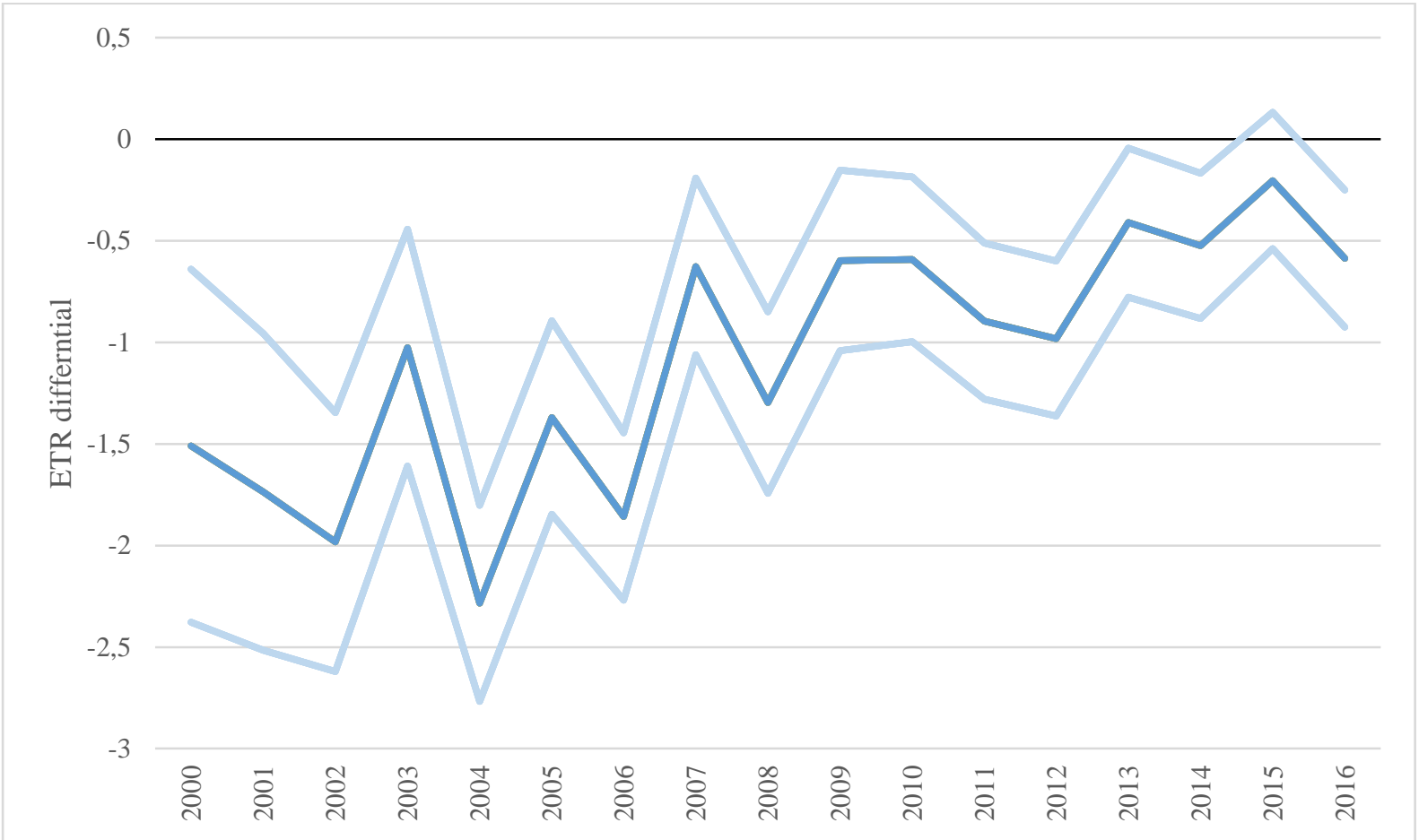

Notes: The dark blue line depicts the annual regression estimates for Indicator 4 and the light blue lines frame the $95 \%$ confidence interval.

\section{Figure 8: Indicator 4 - Trends in international ETR differences (average treatment effects)}

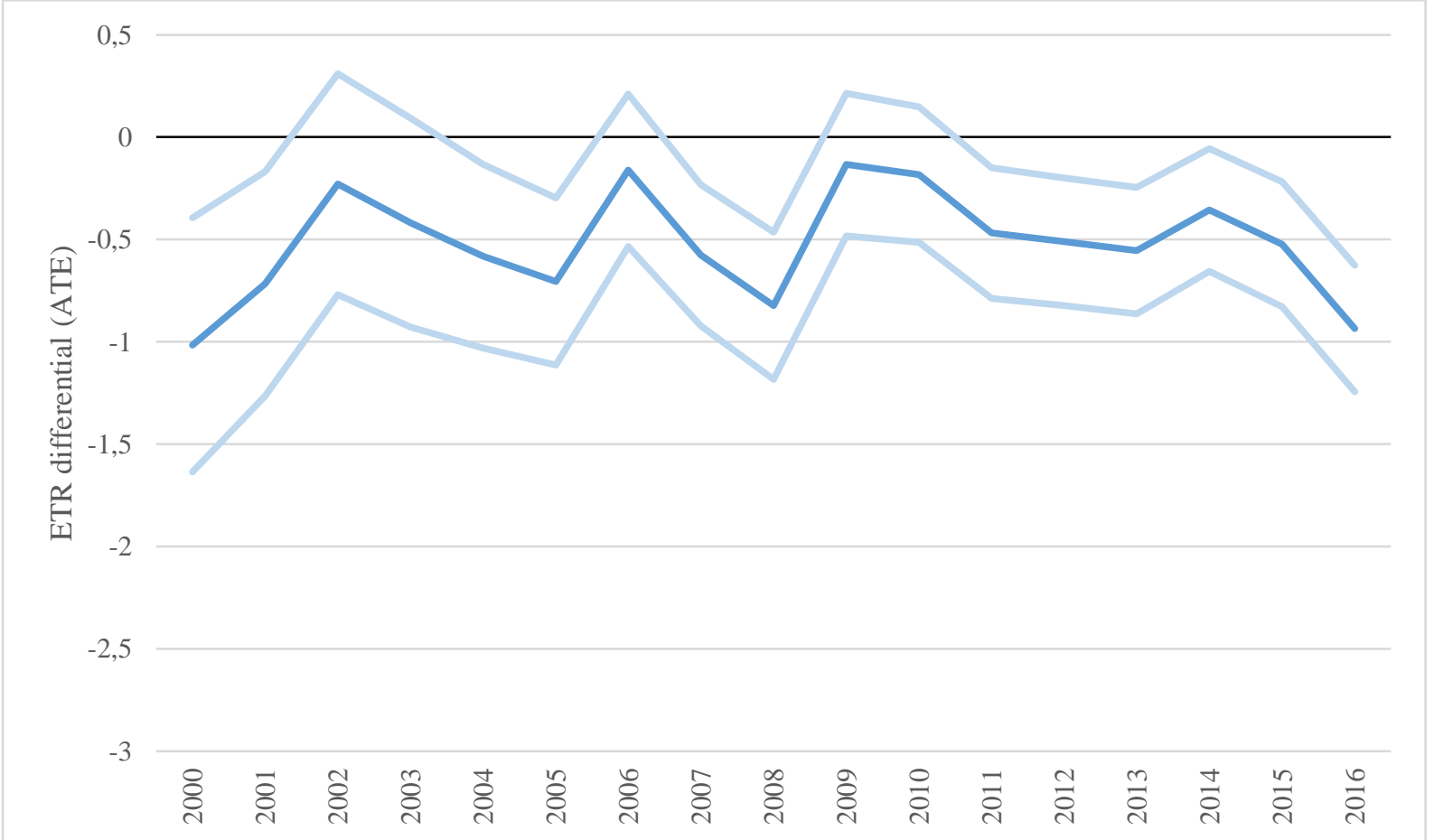

Notes: The dark blue line depicts the annual regression estimates for the ATE, based on the two-step propensity score matching method and the light blue lines frame the $95 \%$ confidence interval. 
Figure 9: Indicator 5 - Royalty receipts to $R \& D$ spending by groups

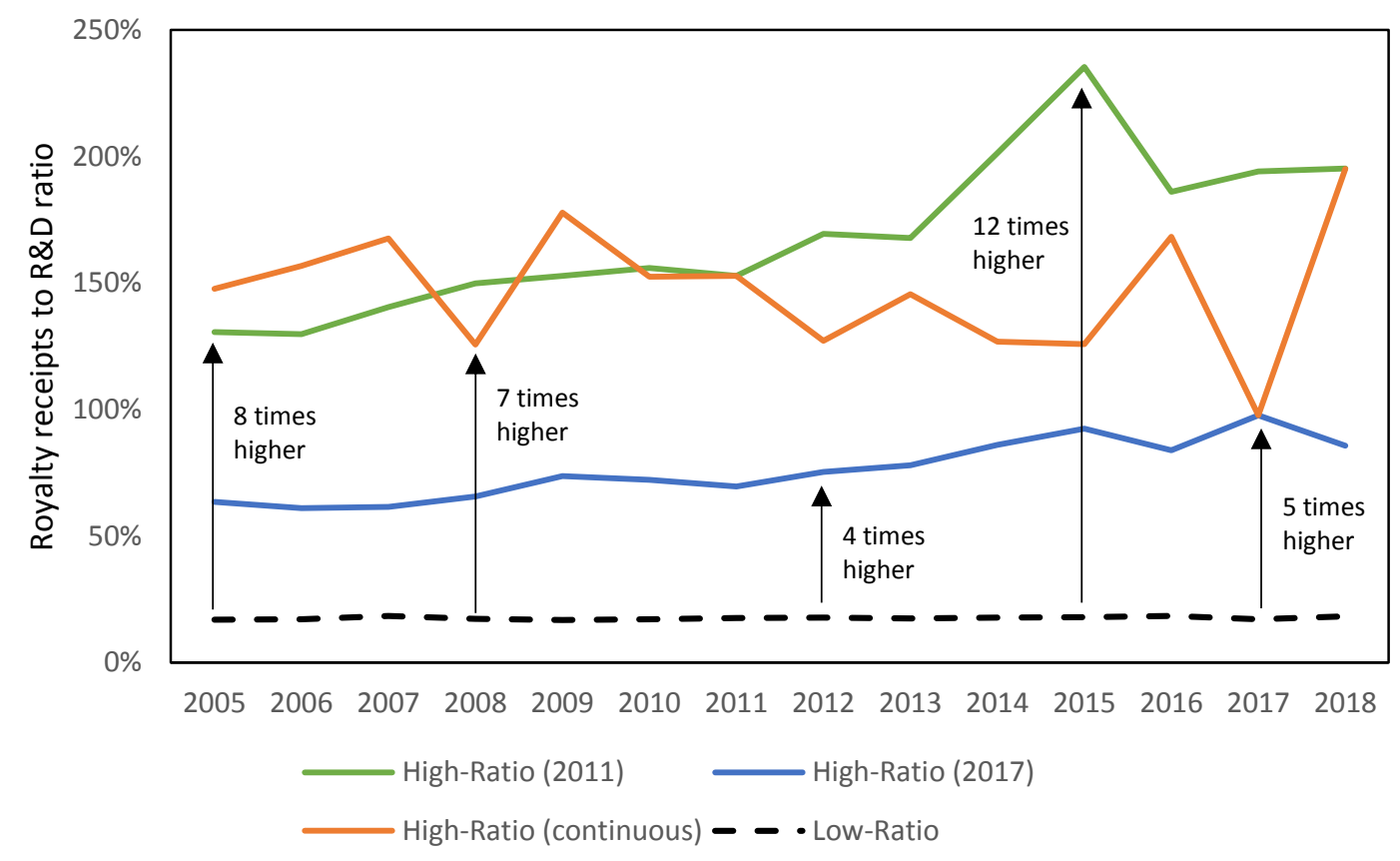

Notes: The green line and blue line depict the trend of the average royalty receipts to $R \& D$ spending ratio for the group of countries that have a ratio above 0.5 in 2011 and 2017, respectively. The orange line depicts the trend of for the group of countries that have a ratio above 0.5 in the particular year. The black dotted line displays the average ratio of the remaining (low-ratio) countries.

\section{Figure 10: Indicator 5 - Indicator trend}

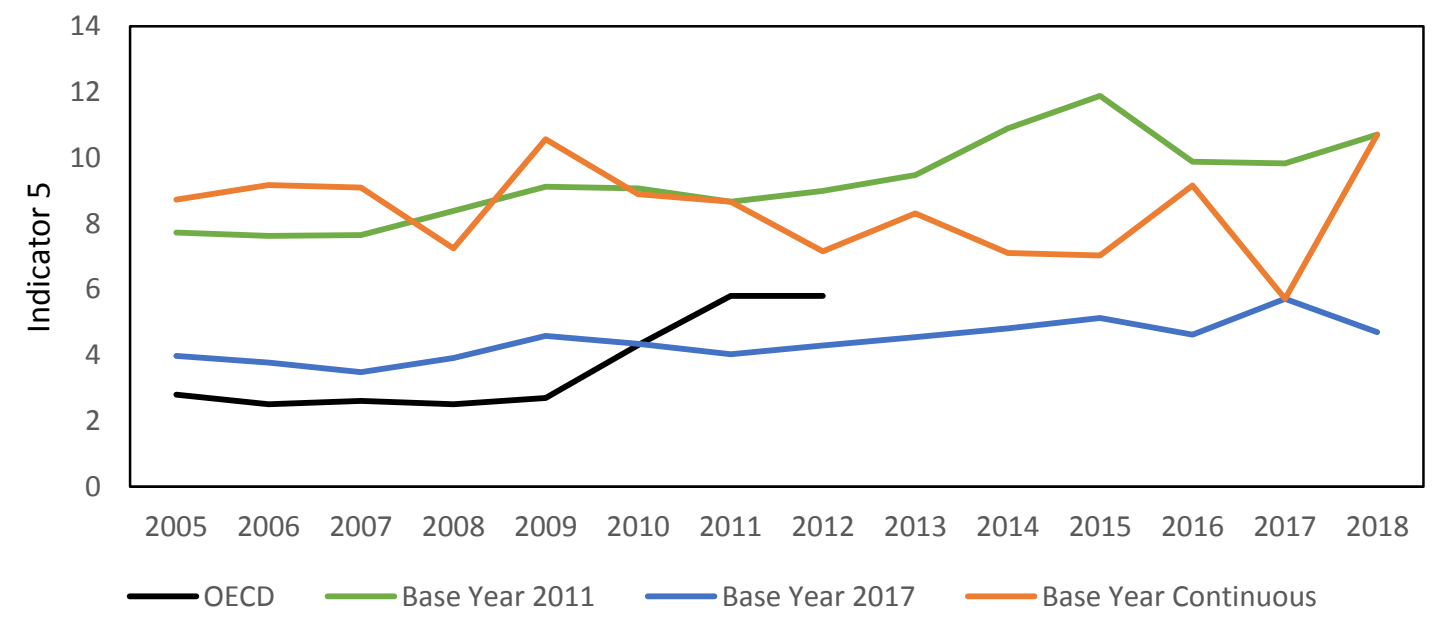

Notes: The green line and blue line shows the trend of Indicator 5 using 2012 or 2018 as base year for group allocation. The orange line redefines the group allocation every year. The black line shows the indicator's trend estimated by the OECD in 2015. 
TABLES

Table 1: Indicator 1 - Country-Year distribution

Panel A

\begin{tabular}{lc}
\hline Year & No of Countries \\
\hline 2005 & 189 \\
2006 & 190 \\
2007 & 190 \\
2008 & 193 \\
2009 & 192 \\
2010 & 195 \\
2011 & 195 \\
2012 & 196 \\
2013 & 198 \\
2014 & 196 \\
2015 & 196 \\
2016 & 195 \\
2017 & 193 \\
2018 & 187 \\
\hline
\end{tabular}

\section{Net FDI}

Gross FDI

Panel B

\begin{tabular}{lc}
\hline Year & No of Countries \\
\hline 2005 & 197 \\
2006 & 200 \\
2007 & 202 \\
2008 & 201 \\
2009 & 200 \\
2010 & 200 \\
2011 & 202 \\
2012 & 202 \\
2013 & 203 \\
2014 & 199 \\
2015 & 199 \\
2016 & 197 \\
2017 & 196 \\
2018 & 191 \\
\hline
\end{tabular}

Notes: The table shows the number of countries with available data per year. Panel A refers to the net FDI to GDP measure. Panel B refers to the gross FDI to GDP measure of Indicator 5. The years 2005 until 2012 rely on the BMD3 definition of Foreign Direct Investment while the years 2013 until 2018 rely on BMD4. 
Table 2: Indicator 1 - Countries in high-ratio group

$\underline{\text { Panel A }}$

\begin{tabular}{lll} 
& Base Year 2012 & Base Year 2018 \\
\hline 1 & Bahamas & Barbados \\
2 & Barbados & Cyprus \\
3 & Bermuda & Dominica \\
4 & Cayman Islands & Ireland \\
5 & Hong Kong & Marshall Islands \\
6 & Hungary & Mauritius \\
7 & Ireland & Mongolia \\
8 & Liberia & Netherlands \\
9 & Malta & Panama \\
10 & Marshall Islands & Papua New Guinea \\
11 & Mauritius & St. Kitts and Nevis \\
12 & Singapore & Singapore \\
13 & St. Kitts and Nevis & Turks and Caicos Islands \\
14 & Trinidad and Tobago & \\
\hline
\end{tabular}

Panel B

\begin{tabular}{lll}
\hline & Base Year 2012 & Base Year 2018 \\
\hline 1 & Bahamas & Bahamas \\
2 & Barbados & Barbados \\
3 & Bermuda & Curacao \\
4 & Cayman Islands & Cyprus \\
5 & Curacao & Ireland \\
6 & Ireland & Luxembourg \\
7 & Luxembourg & Malta \\
8 & Malta & Marshall Islands \\
9 & Marshall Islands & Mauritius \\
10 & Netherlands & Netherlands \\
11 & & Switzerland \\
\hline
\end{tabular}

Notes: The table shows the countries belonging to the high-ratio group. Countries with a ratio above 50 percent are assigned to the group of high-ratio countries while the other countries form the group of low-ratio countries. In Panel A the group structure is shown for the net FDI to GDP measure using base years 2012 and 2018 , respectively. In Panel B the group structure is shown for the gross FDI to GDP measure using base years 2012 and 2018, respectively. 
Table 3: Indicator 1 - Results

Panel A

Net FDI

\begin{tabular}{cc|ccc|ccc}
\hline \multirow{2}{*}{ Year } & OECD & \multicolumn{3}{c}{ Base Year 2012 } & \multicolumn{3}{c}{ Base Year 2018 } \\
& Indicator & High & Low & Indicator & High & Low & Indicator \\
\hline 2005 & 37,6 & $79 \%$ & $2 \%$ & 37,5 & $4 \%$ & $3 \%$ & 1,3 \\
2006 & 36,3 & $89 \%$ & $2 \%$ & 43,1 & $6 \%$ & $3 \%$ & 1,8 \\
2007 & 37,4 & $101 \%$ & $2 \%$ & 44,6 & $26 \%$ & $3 \%$ & 8,0 \\
2008 & 31,9 & $102 \%$ & $3 \%$ & 31,3 & $28 \%$ & $4 \%$ & 6,8 \\
2009 & 41,9 & $134 \%$ & $3 \%$ & 42,3 & $21 \%$ & $5 \%$ & 4,5 \\
2010 & 44,9 & $143 \%$ & $3 \%$ & 44,3 & $23 \%$ & $5 \%$ & 4,8 \\
2011 & 43,1 & $132 \%$ & $3 \%$ & 41,4 & $36 \%$ & $4 \%$ & 8,5 \\
2012 & 99,2 & $157 \%$ & $3 \%$ & 54,8 & $39 \%$ & $4 \%$ & 9,2 \\
2013 & & $102 \%$ & $4 \%$ & 23,9 & $63 \%$ & $4 \%$ & 14,3 \\
2014 & & $105 \%$ & $6 \%$ & 16,3 & $68 \%$ & $7 \%$ & 10,4 \\
2015 & & $100 \%$ & $7 \%$ & 14,6 & $88 \%$ & $7 \%$ & 13,3 \\
2016 & & $96 \%$ & $7 \%$ & 13,9 & $69 \%$ & $7 \%$ & 9,9 \\
2017 & & $91 \%$ & $7 \%$ & 12,9 & $102 \%$ & $6 \%$ & 15,8 \\
2018 & & $77 \%$ & $7 \%$ & 11,7 & $88 \%$ & $6 \%$ & 14,9 \\
\hline
\end{tabular}

Panel B

Gross FDI

\begin{tabular}{cc|ccc|ccc}
\hline \multirow{2}{*}{ Year } & OECD & \multicolumn{3}{c}{ Base Year 2012 } & \multicolumn{3}{c}{ Base Year 2018 } \\
& Indicator & High & Low & Indicator & High & Low & Indicator \\
\hline 2005 & 13,0 & $175 \%$ & $14 \%$ & 12,4 & $125 \%$ & $14 \%$ & 8,9 \\
2006 & 13,9 & $202 \%$ & $15 \%$ & 13,1 & $145 \%$ & $15 \%$ & 9,4 \\
2007 & 15,9 & $247 \%$ & $16 \%$ & 15,0 & $167 \%$ & $17 \%$ & 9,9 \\
2008 & 17,4 & $262 \%$ & $16 \%$ & 16,5 & $176 \%$ & $16 \%$ & 10,9 \\
2009 & 18,9 & $323 \%$ & $18 \%$ & 17,7 & $207 \%$ & $19 \%$ & 11,0 \\
2010 & 21,1 & $349 \%$ & $18 \%$ & 19,9 & $215 \%$ & $18 \%$ & 11,9 \\
2011 & 23,4 & $359 \%$ & $16 \%$ & 22,1 & $215 \%$ & $17 \%$ & 12,8 \\
2012 & 26,7 & $406 \%$ & $17 \%$ & 24,4 & $240 \%$ & $17 \%$ & 14,0 \\
2013 & & $504 \%$ & $21 \%$ & 23,5 & $332 \%$ & $21 \%$ & 15,6 \\
2014 & & $518 \%$ & $23 \%$ & 22,5 & $363 \%$ & $22 \%$ & 16,3 \\
2015 & & $602 \%$ & $25 \%$ & 24,0 & $417 \%$ & $24 \%$ & 17,2 \\
2016 & & $612 \%$ & $26 \%$ & 23,5 & $434 \%$ & $25 \%$ & 17,4 \\
2017 & & $660 \%$ & $27 \%$ & 24,4 & $482 \%$ & $26 \%$ & 18,7 \\
2018 & & $524 \%$ & $25 \%$ & 20,8 & $422 \%$ & $23 \%$ & 18,0 \\
\hline
\end{tabular}

Notes: The table depicts the values of Indicator 1. In Panel A net FDI is used to estimate the indicator. In Panel B gross FDI is used. Column 2 shows Indicator values estimated by the OECD (OECD (2015)). For each country, the ratio of FDI to GDP is calculated. Based on this ratio in a pre-defined base year, countries are assigned to high-ratio groups or low-ratio groups. The threshold values amounts to 50\% in Panel A and 200\% in Panel B. In columns 3 to 52012 is the base year and column 3 and 4 show the ratio of the countries in the high-ratio group and low-ratio group, respectively. Column 5 displays the estimated indicator value. In columns 6 to 8,2018 is the base year and column 6 and 7 show the ratio of the countries in the high-ratio group and lowratio group, respectively. Column 8 displays the estimated indicator value. The years 2005 until 2012 rely on the BMD3 definition of Foreign Direct Investment as data source while the years 2013 until 2018 rely on BMD4. 
Table 4: Indicator 4 - Descriptive Statistics

\begin{tabular}{lrrrrrr} 
Variable & $\mathbf{n}$ & Mean & SD & Min & Median & Max \\
\hline ETR & $5,048,716$ & 31.248 & 20.075 & 0.000 & 28.073 & 100.000 \\
Employees & $5,048,716$ & 136 & 2,477 & 1 & 15 & $1,477,200$ \\
Large dummy & $5,048,716$ & 0.075 & 0.263 & 0.000 & 0.000 & 1.000 \\
MNE dummy & $5,048,716$ & 0.220 & 0.414 & 0.000 & 0.000 & 1.000 \\
Profitability & $5,048,716$ & 0.116 & 0.122 & 0.000 & 0.077 & 1.000 \\
Total Assets (TOAS) & $5,048,716$ & $123,32.850$ & $31,017.534$ & 0.249 & $1,579.236$ & $158,697.237$ \\
Innovation & $5,048,716$ & 0.054 & 0.117 & 0.000 & 0.007 & 0.785 \\
Position in group & $5,048,716$ & 0.684 & 0.465 & 0.000 & 1.000 & 1.000 \\
\hline
\end{tabular}

Notes: The table depicts the descriptive statistics. ETR is the ratio of tax payments to profit and loss before tax. Employees is the number of staff per firm. Large is a dummy variable that is equal to one for all firms with more than 250 employees. MNE is a dummy variable that is equal to one for all firms that belong to a group with a least one cross-border relationship. Profitability is the ratio of earnings before income and taxes (EBIT) to total assets (TOAS), innovation is the ratio of intangible fixed assets (IFAS) to total assets and position in group is a dummy variable that is equal to one for all headquarters. ETR, Profitability, Innovation are measured in percent. Employees in total numbers and total assets in thousand Euro.

\section{Table 5: Indicator 4 - Baseline regression}

\begin{tabular}{lll} 
Variable & $(1)$ & $(2)$ \\
\hline Large & $0.5886^{* * *}$ & $0.7142^{* * *}$ \\
Large x MNE & $(0.0855)$ & $(0.1059)$ \\
& $-0.9606^{* * *}$ & $-1.4648^{* * *}$ \\
Profitability (EBIT/TOAS) & $(0.0982)$ & $(0.1221)$ \\
& $-23.4167^{* * *}$ & $-19.0960^{* * *}$ \\
log Total Assets (TOAS) & $(0.0940)$ & $(0.1095)$ \\
& $-0.2308^{* * *}$ & $-0.1130^{* * *}$ \\
Innovation (IFAS/TOAS) & $(0.0088)$ & $(0.0105)$ \\
& $-2.3959^{* * *}$ & $-3.5671^{* * *}$ \\
Position in Group & $(0.1010)$ & $(0.1148)$ \\
& $-0.7428^{* * *}$ & $-0.8877^{* * *}$ \\
\hline Country-Year Fixed Effects & $(0.0300)$ & $(0.0352)$ \\
Industry Fixed Effects & $\mathrm{x}$ & $\mathrm{x}$ \\
Time limited to 2010 & $\mathrm{x}$ & $\mathrm{x}$ \\
\hline R2 (within) & & $\mathrm{x}$ \\
Number of firms & 0.362 & 0.363 \\
Observations & $1,001,429$ & 751,148 \\
\hline
\end{tabular}

Notes: This table presents the regression results for OECD BEPS Indicator 4. The dependent variable is the effective tax rate (ETR). Large is a dummy variable that is equal to one for all firms with more than 250 employees. MNE is a dummy variable that is equal to one for all firms that belong to a group with a least one cross-border relationship. Profitability is the ratio of earnings before income and taxes (EBIT) to total assets (TOAS), innovation is the ratio of intangible fixed assets (IFAS) to total assets and position in group is a dummy variable that is equal to one for all headquarters. All continuous variables are winsorized at the 1 and 99 percentile. We report standard errors clustered by firm in parentheses. ***, **, * denote statistical significance at the 1 percent, 5 percent, and 10 percent level, respectively. 
Table 6: Indicator 4 - Yearly estimates

\begin{tabular}{|c|c|c|c|c|}
\hline Variable & (1) & (2) & (3) & (4) \\
\hline \multirow[t]{2}{*}{ 2000:Large } & $-0.7736^{*}$ & $-1.0850 * * *$ & $-1.5108 * * *$ & $-2.2380 * * *$ \\
\hline & $(0.3954)$ & $(0.3939)$ & $(0.4585)$ & $(0.4781)$ \\
\hline \multirow[t]{2}{*}{ 2001:Large } & 0.3147 & -0.1126 & -0.5575 & $-1.5111 * * *$ \\
\hline & $(0.3462)$ & $(0.3458)$ & $(0.4338)$ & $(0.4350)$ \\
\hline \multirow[t]{2}{*}{ 2002:Large } & $2.1868 * * *$ & $2.0076^{* * *}$ & $0.9700 * * *$ & -0.5627 \\
\hline & $(0.2877)$ & $(0.2872)$ & $(0.3543)$ & $(0.3896)$ \\
\hline \multirow[t]{2}{*}{ 2003:Large } & $1.9998 * * *$ & $1.7776^{* * *}$ & $1.1361 * * *$ & 0.2366 \\
\hline & $(0.2496)$ & $(0.2487)$ & $(0.3303)$ & $(0.3794)$ \\
\hline \multirow[t]{2}{*}{ 2004:Large } & $2.4646^{* * *}$ & $2.3151 * * *$ & $1.6728 * * *$ & $0.8735^{* *}$ \\
\hline & $(0.2148)$ & $(0.2143)$ & $(0.3107)$ & $(0.3476)$ \\
\hline \multirow[t]{2}{*}{ 2005:Large } & $1.6306^{* * *}$ & $1.4252 * * *$ & $0.6555 * *$ & -0.1470 \\
\hline & $(0.2075)$ & $(0.2087)$ & $(0.2853)$ & $(0.3082)$ \\
\hline \multirow[t]{2}{*}{ 2006:Large } & $1.7789 * * *$ & $1.4896^{* * *}$ & 0.0942 & $-0.4781^{*}$ \\
\hline & $(0.1828)$ & $(0.1835)$ & $(0.2573)$ & $(0.2764)$ \\
\hline \multirow[t]{2}{*}{ 2007:Large } & $0.7786 * * *$ & $0.3788 * *$ & $-0.7637 * * *$ & $-1.3707 * * *$ \\
\hline & $(0.1840)$ & (0.1859) & $(0.2478)$ & $(0.2505)$ \\
\hline \multirow[t]{2}{*}{ 2008:Large } & $1.0072 * * *$ & $0.6677 * * *$ & 0.1081 & $-0.9128 * * *$ \\
\hline & $(0.1883)$ & $(0.1897)$ & $(0.2579)$ & $(0.2527)$ \\
\hline \multirow[t]{2}{*}{ 2009:Large } & $0.3695^{*}$ & 0.1497 & $-0.5623^{* *}$ & $-1.3280 * * *$ \\
\hline & $(0.1894)$ & $(0.1901)$ & $(0.2498)$ & $(0.2600)$ \\
\hline \multirow[t]{2}{*}{ 2010:Large } & 0.2563 & 0.0688 & -0.2922 & $-1.0931 * * *$ \\
\hline & $(0.1759)$ & $(0.1767)$ & $(0.2338)$ & $(0.2493)$ \\
\hline \multirow[t]{2}{*}{ 2011:Large } & $1.3874 * * *$ & $1.1905^{* * *}$ & $0.8417 * * *$ & 0.3256 \\
\hline & $(0.1664)$ & $(0.1671)$ & $(0.2229)$ & $(0.2426)$ \\
\hline \multirow[t]{2}{*}{ 2012:Large } & $0.9766^{* * *}$ & $0.8262 * * *$ & 0.2858 & -0.1289 \\
\hline & $(0.1652)$ & $(0.1659)$ & $(0.2246)$ & $(0.2493)$ \\
\hline \multirow[t]{2}{*}{ 2013:Large } & $0.4664 * * *$ & $0.3126 * *$ & -0.1981 & $-1.0866 * * *$ \\
\hline & $(0.1581)$ & $(0.1591)$ & $(0.2142)$ & $(0.2350)$ \\
\hline \multirow[t]{2}{*}{ 2014:Large } & $0.4995^{* * *}$ & $0.3621 * *$ & 0.2058 & $-0.8728 * * *$ \\
\hline & $(0.1556)$ & $(0.1565)$ & $(0.2110)$ & $(0.2286)$ \\
\hline \multirow[t]{2}{*}{ 2015:Large } & $-0.3790 * * *$ & $-0.4503 * * *$ & $-0.7946 * * *$ & $-1.7849 * * *$ \\
\hline & $(0.1449)$ & $(0.1463)$ & $(0.1934)$ & $(0.2139)$ \\
\hline \multirow[t]{2}{*}{ 2016:Large } & $-0.6421 * * *$ & $-0.6898 * * *$ & $-1.0967 * * *$ & $-1.9308 * * *$ \\
\hline & $(0.1468)$ & $(0.1482)$ & $(0.1963)$ & $(0.2175)$ \\
\hline \multirow[t]{2}{*}{ 2000:Large x MNE } & $-1.7451 * * *$ & $-1.5094 * * *$ & $-1.6024 * * *$ & $-1.3151 * *$ \\
\hline & $(0.4446)$ & $(0.4435)$ & $(0.4997)$ & $(0.5462)$ \\
\hline \multirow[t]{2}{*}{ 2001:Large x MNE } & $-2.0168 * * *$ & $-1.7351 * * *$ & $-1.6660 * * *$ & $-1.0466^{* *}$ \\
\hline & $(0.3979)$ & $(0.3978)$ & $(0.4783)$ & $(0.4984)$ \\
\hline \multirow[t]{2}{*}{ 2002:Large x MNE } & $-2.1409 * * *$ & $-1.9829 * * *$ & $-1.1959 * * *$ & $-1.0171 * *$ \\
\hline & $(0.3257)$ & $(0.3253)$ & $(0.3976)$ & $(0.4454)$ \\
\hline \multirow[t]{2}{*}{ 2003:Large x MNE } & $-1.2244 * * *$ & $-1.0260 * * *$ & $-1.0556 * * *$ & $-1.2429 * * *$ \\
\hline & $(0.2988)$ & $(0.2978)$ & $(0.3723)$ & $(0.4335)$ \\
\hline \multirow[t]{2}{*}{ 2004:Large x MNE } & $-2.4361 * * *$ & $-2.2845^{* * * *}$ & $-1.8052 * * *$ & $-1.6114 * * *$ \\
\hline & $(0.2469)$ & $(0.2463)$ & $(0.3470)$ & $(0.3947)$ \\
\hline \multirow[t]{2}{*}{ 2005:Large x MNE } & $-1.5695 * * *$ & $-1.3694 * * *$ & $-1.0705 * * *$ & $-0.9054 * *$ \\
\hline & & 35 & & \\
\hline
\end{tabular}




\begin{tabular}{|c|c|c|c|c|}
\hline & $(0.2423)$ & $(0.2431)$ & $(0.3185)$ & $(0.3516)$ \\
\hline \multirow[t]{2}{*}{ 2006:Large x MNE } & $-2.0878 * * *$ & $-1.8566 * * *$ & $-0.7579 * * *$ & $-0.7890 * *$ \\
\hline & $(0.2100)$ & $(0.2101)$ & $(0.2895)$ & $(0.3176)$ \\
\hline \multirow[t]{2}{*}{ 2007:Large x MNE } & $-0.9689 * * *$ & $-0.6266^{* * *}$ & -0.3101 & -0.0279 \\
\hline & $(0.2208)$ & $(0.2219)$ & $(0.2812)$ & $(0.2908)$ \\
\hline \multirow[t]{2}{*}{ 2008:Large x MNE } & $-1.5318 * * *$ & $-1.2965 * * *$ & $-1.5250 * * *$ & $-0.8234 * * *$ \\
\hline & $(0.2275)$ & $(0.2279)$ & $(0.2937)$ & $(0.2941)$ \\
\hline \multirow[t]{2}{*}{ 2009:Large x MNE } & $-0.8038 * * *$ & $-0.5968 * * *$ & -0.2437 & -0.2402 \\
\hline & $(0.2269)$ & $(0.2268)$ & $(0.2890)$ & $(0.3038)$ \\
\hline \multirow{2}{*}{ 2010:Large x MNE } & $-0.8344 * * *$ & $-0.5917 * * *$ & $-0.7783 * * *$ & $-0.7657 * * *$ \\
\hline & $(0.2069)$ & $(0.2069)$ & $(0.2680)$ & $(0.2868)$ \\
\hline \multirow[t]{2}{*}{ 2011:Large x MNE } & $-1.1547 * * *$ & $-0.8956 * * *$ & $-1.0909 * * *$ & $-1.6932 * * *$ \\
\hline & $(0.1966)$ & $(0.1964)$ & $(0.2576)$ & $(0.2806)$ \\
\hline \multirow[t]{2}{*}{ 2012:Large x MNE } & $-1.1871 * * *$ & $-0.9812 * * *$ & $-1.3222 * * *$ & $-1.6207 * * *$ \\
\hline & $(0.1950)$ & $(0.1949)$ & $(0.2575)$ & $(0.2894)$ \\
\hline \multirow[t]{2}{*}{ 2013:Large x MNE } & $-0.5882 * * *$ & $-0.4110 * *$ & $-0.5016^{* *}$ & $-0.4745^{*}$ \\
\hline & $(0.1872)$ & $(0.1873)$ & $(0.2463)$ & $(0.2750)$ \\
\hline \multirow[t]{2}{*}{ 2014:Large x MNE } & $-0.7135 * * *$ & $-0.5245 * * *$ & $-0.9343 * * *$ & $-0.6510 * *$ \\
\hline & $(0.1825)$ & $(0.1826)$ & $(0.2418)$ & $(0.2673)$ \\
\hline \multirow[t]{2}{*}{ 2015:Large x MNE } & $-0.3270^{*}$ & -0.2036 & $-0.5201 * *$ & -0.0968 \\
\hline & $(0.1705)$ & $(0.1711)$ & $(0.2225)$ & $(0.2520)$ \\
\hline \multirow[t]{2}{*}{ 2016:Large x MNE } & $-0.7032 * * *$ & $-0.5873 * * *$ & $-1.0718 * * *$ & $-0.6808 * * *$ \\
\hline & $(0.1720)$ & $(0.1724)$ & $(0.2241)$ & $(0.2530)$ \\
\hline \multirow[t]{2}{*}{ Profitability (EBIT/TOAS) } & & $-23.4167 * * *$ & $-23.5781 * * *$ & $-26.1302 * * *$ \\
\hline & & $(0.0940)$ & $(0.1250)$ & $(0.1065)$ \\
\hline \multirow[t]{2}{*}{ log Total Assets (TOAS) } & & $-0.2317 * * *$ & $-0.0433 * * *$ & $-0.3191 * * *$ \\
\hline & & $(0.0088)$ & $(0.0102)$ & $(0.0098)$ \\
\hline \multirow[t]{2}{*}{ Innovation (IFAS/TOAS) } & & $-2.3973 * * *$ & $-2.3508 * * *$ & $-2.6047 * * *$ \\
\hline & & $(0.1010)$ & $(0.1048)$ & $(0.1057)$ \\
\hline \multirow[t]{2}{*}{ Position in Group (GUO=1) } & & $-0.7448 * * *$ & $-0.5962 * * *$ & $-0.8345 * * *$ \\
\hline & & $(0.0300)$ & $(0.0328)$ & $(0.0337)$ \\
\hline Country-Year Fixed Effects & $\mathrm{x}$ & $\mathrm{x}$ & $\mathrm{x}$ & $\mathrm{x}$ \\
\hline Industry Fixed Effects & $\mathrm{x}$ & $\mathrm{x}$ & $\mathrm{x}$ & $\mathrm{x}$ \\
\hline Country Restriction & - & - & OECD & EU \\
\hline R2 (within) & 0.345 & 0.362 & 0.354 & 0.365 \\
\hline Number of firms & $1,001,429$ & $1,001,429$ & 843,911 & 854,141 \\
\hline Observations & $5,048,716$ & $5,048,716$ & $4,320,449$ & $4,353,789$ \\
\hline
\end{tabular}

Notes: This table presents the regression results for OECD BEPS Indicator 4. The dependent variable is the effective tax rate (ETR). Large is a dummy variable that is equal to one for all firms with more than 250 employees. MNE is a dummy variable that is equal to one for all firms that belong to a group with a least one cross-border relationship. Profitability is the ratio of earnings before income and taxes (EBIT) to total assets (TOAS), innovation is the ratio of intangible fixed assets (IFAS) to total assets and position in group is a dummy variable that is equal to one for all headquarters. The dummy variables of interest are interacted with a year dummy to provide annual estimates. All continuous variables are winsorized at the 1 and 99 percentile. We report standard errors clustered by firm in parentheses. ***, **, * denote statistical significance at the 1 percent, 5 percent, and 10 percent level, respectively. 
Table 7: Indicator 4 - Robustness change of outcome variable

\begin{tabular}{|c|c|}
\hline Variable & (1) \\
\hline \multirow[t]{2}{*}{ 2000:Large x MNE } & -0.0151 \\
\hline & $(0.0597)$ \\
\hline \multirow[t]{2}{*}{ 2001:Large x MNE } & $-0.1056^{* *}$ \\
\hline & $(0.0464)$ \\
\hline \multirow{2}{*}{ 2002:Large x MNE } & $-0.1709 * * *$ \\
\hline & $(0.0361)$ \\
\hline \multirow[t]{2}{*}{ 2003:Large x MNE } & -0.0489 \\
\hline & $(0.0328)$ \\
\hline \multirow[t]{2}{*}{ 2004:Large x MNE } & $-0.1017 * * *$ \\
\hline & $(0.0275)$ \\
\hline \multirow[t]{2}{*}{ 2005:Large x MNE } & $-0.0553 *$ \\
\hline & $(0.0297)$ \\
\hline \multirow[t]{2}{*}{ 2006:Large x MNE } & $-0.1501 * * *$ \\
\hline & $(0.0244)$ \\
\hline \multirow[t]{2}{*}{ 2007:Large x MNE } & $-0.0983 * * *$ \\
\hline & $(0.0258)$ \\
\hline \multirow[t]{2}{*}{ 2008:Large x MNE } & $-0.1209 * * *$ \\
\hline & $(0.0255)$ \\
\hline \multirow[t]{2}{*}{ 2009:Large x MNE } & $-0.0399 *$ \\
\hline & $(0.0221)$ \\
\hline \multirow[t]{2}{*}{ 2010:Large x MNE } & $-0.0697 * * *$ \\
\hline & $(0.0200)$ \\
\hline \multirow[t]{2}{*}{ 2011:Large x MNE } & $-0.1158 * * *$ \\
\hline & $(0.0198)$ \\
\hline \multirow[t]{2}{*}{ 2012:Large x MNE } & $-0.1221 * * *$ \\
\hline & $(0.0188)$ \\
\hline \multirow[t]{2}{*}{ 2013:Large x MNE } & $-0.0537 * * *$ \\
\hline & $(0.0179)$ \\
\hline \multirow[t]{2}{*}{ 2014:Large x MNE } & $-0.0632 * * *$ \\
\hline & $(0.0178)$ \\
\hline \multirow[t]{2}{*}{ 2015:Large x MNE } & $-0.0483 * * *$ \\
\hline & $(0.0173)$ \\
\hline \multirow[t]{2}{*}{ 2016:Large x MNE } & $-0.0883 * * *$ \\
\hline & $(0.0177)$ \\
\hline Country-Year Fixed Effects & $\mathrm{X}$ \\
\hline Industry Fixed Effects & $\mathrm{x}$ \\
\hline Controls & $\mathrm{X}$ \\
\hline R2 (within) & 0.666 \\
\hline Number of firms & $1,001,429$ \\
\hline Observations & $5,048,716$ \\
\hline
\end{tabular}

Notes: This table presents the regression results for OECD BEPS Indicator 4. The dependent variable is the ratio of tax payments to total assets (TOAS). Large is a dummy variable that is equal to one for all firms with more than 250 employees. MNE is a dummy variable that is equal to one for all firms that belong to a group with a least one cross-border relationship. For the sake of brevity, we do not display the coefficient estimates for the control variables: Profitability is the ratio of earnings before income and taxes (EBIT) to total assets (TOAS), innovation is the ratio of intangible fixed assets (IFAS) to total assets and position in group is a dummy variable that is equal to one for all headquarters. The dummy variables of interest are interacted with a year dummy to provide annual estimates. All continuous variables are winsorized at the 1 and 99 percentile. We report standard errors clustered by firm in parentheses. $* * *, * *, *$ denote statistical significance at the 1 percent, 5 percent, and 10 percent level, respectively. 
Table 8: Indicator 4 - Propensity score matching evaluation

Matching Evaluation

\begin{tabular}{lrrrrr}
\hline & Standardized Differences & \multicolumn{3}{c}{ Variance Ratio } \\
& Raw & Matched & Bias reduction & Raw & Matched \\
\hline $\ln ($ TOAS) & 1.2628 & -0.0134 & $98.94 \%$ & 1.3302 & 0.9296 \\
$\ln ($ PROD) & 0.1151 & -0.0351 & $69.51 \%$ & 1.0248 & 0.9369 \\
D/E Ratio & -0.2246 & 0.0267 & $88.14 \%$ & 0.4634 & 0.9854 \\
Innovation & -0.0967 & -0.0091 & $90.57 \%$ & 0.8897 & 0.9408 \\
\hline
\end{tabular}

Notes: This table presents the evaluation of the matching procedure on the logarithm of total assets (TOAS), the logarithm of productivity (PROD), which is the ratio of sales to total wages, the debt to equity ratio, and innovation, which is the ratio of intangible fixed assets (IFAS) to total assets (TOAS). The column Raw depicts the standardized differences and variance ratios in the unmatched sample. The column Matched depicts the standardized differences and variance ratios in the matched sample. The column Bias Reduction is the percentage reduction in the standardized differences between the unmatched and matched sample. The values depict the averages of all years. Standardized differences close to 0 and variance ratios close to 1 are indicators of a good matching quality. 
Table 9: Indicator 4 - Propensity score matching estimates on the ETR difference (ATE)

\begin{tabular}{|c|c|}
\hline Year & ATE \\
\hline \multirow[t]{2}{*}{2000} & $-1.0154 * * *$ \\
\hline & $(0.3164)$ \\
\hline \multirow[t]{2}{*}{2001} & $-0.7162 * *$ \\
\hline & $(0.2794)$ \\
\hline \multirow[t]{2}{*}{2002} & -0.2295 \\
\hline & $(0.2754)$ \\
\hline \multirow[t]{2}{*}{2003} & -0.4179 \\
\hline & $(0.2605)$ \\
\hline \multirow[t]{2}{*}{2004} & $-0.5825 * *$ \\
\hline & $(0.2290)$ \\
\hline \multirow[t]{2}{*}{2005} & $-0.7053 * * *$ \\
\hline & $(0.2086)$ \\
\hline \multirow[t]{2}{*}{2006} & -0.1611 \\
\hline & $(0.1900)$ \\
\hline \multirow[t]{2}{*}{2007} & $-0.5774 * * *$ \\
\hline & $(0.1758)$ \\
\hline \multirow[t]{2}{*}{2008} & $-0.8239 * * *$ \\
\hline & $(0.1835)$ \\
\hline \multirow[t]{2}{*}{2009} & -0.1339 \\
\hline & $(0.1780)$ \\
\hline \multirow[t]{2}{*}{2010} & -0.1824 \\
\hline & $(0.1688)$ \\
\hline \multirow[t]{2}{*}{2011} & $-0.4686^{* * *}$ \\
\hline & $(0.1627)$ \\
\hline \multirow[t]{2}{*}{2012} & $-0.5112 * * *$ \\
\hline & $(0.1591)$ \\
\hline \multirow[t]{2}{*}{2013} & $-0.5548 * * *$ \\
\hline & $(0.1576)$ \\
\hline \multirow[t]{2}{*}{2014} & $-0.3559 * *$ \\
\hline & $(0.1528)$ \\
\hline \multirow[t]{2}{*}{2015} & $-0.5237 * * *$ \\
\hline & $(0.1555)$ \\
\hline \multirow[t]{2}{*}{2016} & $-0.9351 * * *$ \\
\hline & $(0.1572)$ \\
\hline
\end{tabular}

Observations

$3,669,138$

Notes: The table depicts the annual average treatment effects (ATE) of being a multinational corporation on the ETR. The ATE estimates are based on a propensity score estimation procedure. The groups of multinational and domestic firms are matched on the logarithm of total assets (TOAS), the logarithm of productivity (PROD), which is the ratio of sales to total wages, the debt to equity ratio and innovation, which is the ratio of intangible fixed assets (IFAS) to total assets (TOAS). Standard errors are rely on the adjustment by Abadie and Imbens (2012) and take into account that the propensity scores to match the groups are estimated. ***,**,* denote statistical significance at the 1 percent, 5 percent, and 10 percent level, respectively. 


\begin{tabular}{lc} 
Year & No of Countries \\
\hline 2005 & 64 \\
2006 & 60 \\
2007 & 72 \\
2008 & 70 \\
2009 & 70 \\
2010 & 70 \\
2011 & 69 \\
2012 & 68 \\
2013 & 74 \\
2014 & 68 \\
2015 & 74 \\
2016 & 72 \\
2017 & 76 \\
2018 & 56 \\
\hline
\end{tabular}

Notes: The table shows the number of countries with available data on receipts for the use of IP as balance of payments in current US dollar from the World Bank and available data on the gross domestic expenditure on $\mathrm{R} \& \mathrm{D}$ from the UNESCO Institute for Statistics per year.

Table 11: Indicator 5 - Countries in the high-ratio group

Base Year 2011

Base Year 2017

\begin{tabular}{lll}
\hline 1 & Guatemala & El Salvador \\
2 & Hungary & Hungary \\
3 & Ireland & Luxembourg \\
4 & Lesotho & Madagascar \\
5 & Luxembourg & Malta \\
6 & Madagascar & Netherlands \\
7 & Malta & Singapore \\
8 & Netherlands & Switzerland \\
9 & & United Kingdom \\
\hline
\end{tabular}

Notes: The table shows the countries belonging to the high-ratio group. High-ratio countries are those countries that have a royalty receipts to R\&D spending ratio of above 0.5 in a pre-defined base year. Column 1 and 2 refer to base years 2011 and 2017, respectively. 
Table 12: Indicator 5 - Results

\begin{tabular}{|c|c|c|c|c|c|c|c|c|c|c|}
\hline \multirow{2}{*}{ Year } & \multirow{2}{*}{$\begin{array}{c}\text { OECD } \\
\text { Indicator }\end{array}$} & \multicolumn{3}{|c|}{ Base Year: 2011} & \multicolumn{3}{|c|}{ Base Year: 2017} & \multicolumn{3}{|c|}{ Base Year: Continuous } \\
\hline & & High & Low & Indicator & High & Low & Indicator & High & Low & Indicator \\
\hline 2005 & 2,8 & $131 \%$ & $17 \%$ & 7,7 & $64 \%$ & $16 \%$ & 4,0 & $148 \%$ & $17 \%$ & 8,7 \\
\hline 2006 & 2,5 & $130 \%$ & $17 \%$ & 7,6 & $61 \%$ & $16 \%$ & 3,8 & $157 \%$ & $17 \%$ & 9,2 \\
\hline 2007 & 2,6 & $140 \%$ & $18 \%$ & 7,7 & $62 \%$ & $18 \%$ & 3,5 & $168 \%$ & $18 \%$ & 9,1 \\
\hline 2008 & 2,5 & $150 \%$ & $18 \%$ & 8,4 & $66 \%$ & $17 \%$ & 3,9 & $126 \%$ & $17 \%$ & 7,2 \\
\hline 2009 & 2,7 & $153 \%$ & $17 \%$ & 9,1 & $74 \%$ & $16 \%$ & 4,6 & $178 \%$ & $17 \%$ & 10,6 \\
\hline 2010 & 4,3 & $156 \%$ & $17 \%$ & 9,1 & $72 \%$ & $17 \%$ & 4,3 & $152 \%$ & $17 \%$ & 8,9 \\
\hline 2011 & 5,8 & $153 \%$ & $18 \%$ & 8,7 & $70 \%$ & $17 \%$ & 4,0 & $153 \%$ & $18 \%$ & 8,7 \\
\hline 2012 & 5,8 & $169 \%$ & $19 \%$ & 9,0 & $75 \%$ & $18 \%$ & 4,3 & $127 \%$ & $18 \%$ & 7,2 \\
\hline 2013 & & $168 \%$ & $18 \%$ & 9,5 & $78 \%$ & $17 \%$ & 4,5 & $146 \%$ & $18 \%$ & 8,3 \\
\hline 2014 & & $201 \%$ & $18 \%$ & 10,9 & $86 \%$ & $18 \%$ & 4,8 & $127 \%$ & $18 \%$ & 7,1 \\
\hline 2015 & & $235 \%$ & $20 \%$ & 11,9 & $92 \%$ & $18 \%$ & 5,1 & $126 \%$ & $18 \%$ & 7,0 \\
\hline 2016 & & $186 \%$ & $19 \%$ & 9,9 & $84 \%$ & $18 \%$ & 4,6 & $168 \%$ & $18 \%$ & 9,2 \\
\hline 2017 & & $194 \%$ & $20 \%$ & 9,8 & $98 \%$ & $17 \%$ & 5,7 & $98 \%$ & $17 \%$ & 5,7 \\
\hline 2018 & & $195 \%$ & $18 \%$ & 10,7 & $86 \%$ & $18 \%$ & 4,7 & $195 \%$ & $18 \%$ & 10,7 \\
\hline
\end{tabular}

$\pm \quad$ Notes: The table depicts the values of Indicator 5. Column 2 shows Indicator values estimated by the OECD (OECD, 2015). For each country the ratio of royalty receipts to $\mathrm{R} \& \mathrm{D}$ spending is calculated. Based on this ratio in a pre-defined base year, countries are assigned to high-ratio groups or low-ratio groups. The threshold values amounts to $50 \%$. Column 3 and 4 show the ratio of the countries in the high-ratio group and low-ratio group, respectively. Column 5 shows the estimated indicator value. Each panel refers to a different base year for group assignment. The Worldbank and UNESCO are used as data source. 
Table 13: Indicator 5 - Results alternative data

\begin{tabular}{|c|c|c|c|c|c|c|c|c|c|c|}
\hline \multirow{2}{*}{ Year } & \multirow{2}{*}{$\begin{array}{c}\text { OECD } \\
\text { Indicator }\end{array}$} & \multicolumn{3}{|c|}{ Base Year: 2011} & \multicolumn{3}{|c|}{ Base Year: 2017} & \multicolumn{3}{|c|}{ Base Year: Continuous } \\
\hline & & High & Low & Indicator & High & Low & Indicator & High & Low & Indicator \\
\hline 2005 & 2,8 & $111 \%$ & $13 \%$ & 8,2 & $78 \%$ & $14 \%$ & 5,7 & $143 \%$ & $14 \%$ & 10,5 \\
\hline 2006 & 2,5 & $112 \%$ & $14 \%$ & 8,1 & $102 \%$ & $14 \%$ & 7,3 & $148 \%$ & $14 \%$ & 10,7 \\
\hline 2007 & 2,6 & $137 \%$ & $16 \%$ & 8,8 & $117 \%$ & $16 \%$ & 7,5 & $182 \%$ & $16 \%$ & 11,6 \\
\hline 2008 & 2,5 & $157 \%$ & $16 \%$ & 9,8 & $89 \%$ & $16 \%$ & 5,7 & $134 \%$ & $16 \%$ & 8,6 \\
\hline 2009 & 2,7 & $148 \%$ & $14 \%$ & 10,2 & $101 \%$ & $15 \%$ & 6,9 & $170 \%$ & $15 \%$ & 11,7 \\
\hline 2010 & 4,3 & $144 \%$ & $15 \%$ & 9,4 & $96 \%$ & $15 \%$ & 6,2 & $144 \%$ & $15 \%$ & 9,4 \\
\hline 2011 & 5,8 & $154 \%$ & $17 \%$ & 9,3 & $101 \%$ & $17 \%$ & 6,0 & $154 \%$ & $17 \%$ & 9,3 \\
\hline 2012 & 5,8 & $160 \%$ & $17 \%$ & 9,3 & $110 \%$ & $16 \%$ & 6,7 & $117 \%$ & $16 \%$ & 7,4 \\
\hline 2013 & & $164 \%$ & $16 \%$ & 10,2 & $116 \%$ & $16 \%$ & 7,2 & $122 \%$ & $16 \%$ & 7,8 \\
\hline 2014 & & $198 \%$ & $17 \%$ & 12,0 & $135 \%$ & $17 \%$ & 8,1 & $148 \%$ & $16 \%$ & 9,2 \\
\hline 2015 & & $197 \%$ & $17 \%$ & 11,8 & $128 \%$ & $16 \%$ & 8,1 & $126 \%$ & $15 \%$ & 8,3 \\
\hline 2016 & & $156 \%$ & $16 \%$ & 10,0 & $112 \%$ & $16 \%$ & 7,1 & $130 \%$ & $15 \%$ & 8,5 \\
\hline 2017 & & $166 \%$ & $17 \%$ & 9,9 & $129 \%$ & $15 \%$ & 8,4 & $129 \%$ & $15 \%$ & 8,4 \\
\hline 2018 & & $179 \%$ & $16 \%$ & 11,4 & $147 \%$ & $16 \%$ & 9,0 & $202 \%$ & $16 \%$ & 12,9 \\
\hline
\end{tabular}

Notes: The table depicts the values of Indicator 5. Column 2 shows Indicator values estimated by the OECD (OECD, 2015). For each country the ratio of royalty receipts to
R\&D spending is calculated. Based on this ratio in a pre-defined base year, countries are assigned to high-ratio groups or low-ratio groups. The threshold values amounts to $50 \%$. Column 3 and 4 show the ratio of the countries in the high-ratio group and low-ratio group, respectively. Column 5 shows the estimated indicator value. Each panel refers to a different base year for group assignment. The Worldbank and OECD are used as data source. 
Download ZEW Discussion Papers from our ftp server:

http://ftp.zew.de/pub/zew-docs/dp/

or see:

https://www.ssrn.com/link/ZEW-Ctr-Euro-Econ-Research.html

https://ideas.repec.org/s/zbw/zewdip.html

$$
\text { // }
$$

IMPRINT

ZEW - Leibniz-Zentrum für Europäische Wirtschaftsforschung GmbH Mannheim

ZEW - Leibniz Centre for European

Economic Research

L 7,1 68161 Mannheim · Germany

Phone +49621 1235-01

info@zew.de·zew.de

Discussion Papers are intended to make results of ZEW research promptly available to other economists in order to encourage discussion and suggestions for revisions. The authors are solely responsible for the contents which do not necessarily represent the opinion of the ZEW. 